\title{
Quantitative analysis of Cenozoic faults and fractures and their impact on groundwater flow in the bedrock aquifers of Ireland
}

\author{
J. P. Moore ${ }^{1,2} \cdot$ J. J. Walsh ${ }^{1}$ \\ Received: 1 September 2020 / Accepted: 10 August 2021 / Published online: 5 October 2021 \\ (C) The Author(s) 2021
}

\begin{abstract}
Faults and fractures are a critical store and pathway for groundwater in Ireland's limestone bedrock aquifers either directly as conductive structures or indirectly as the locus for the development of karst conduits. From the quantitative analysis of postDevonian faults and fractures in a range of lithological sequences, this report describes the principal characteristics of Cenozoic strike-slip faults and joints, the youngest and the most intrinsically conductive fractures within Irish bedrock. Analysis of these structures in more than 120 outcrop, quarry, mine and cave locations in a range of bedrock types, provides a basis for: (1) definition of quantitative models for their depth dependency, lithological control, scaling systematics and links to preexisting structure, (2) conceptualisation of their impact on groundwater behaviour, and (3) estimation of groundwater flow parameters. The quantitative models provide constraints on fracture-controlled flow connectivity. Commonly observed decreases in sustainable flows and water strike interceptions with depth are attributed to increasing confinement and decreasing fracture connectivity and dissolution. Faults and joints have quite different end member geometries, with faults having strongly heterogeneous scaleindependent properties and joints more often showing scale-dependent stratabound properties. The highest and most sustainable groundwater flows are usually associated with the complexity of structure of Cenozoic faults and of preexisting Carboniferous structures (on which conductive fracturing localises), enhanced by karstification and strongly jointed limestone bedrock particularly in the near-surface. Increased groundwater flow is promoted within bedded, rather than massive (i.e. unbedded), limestone sequences, characterised by bedding-parallel fractures and karst connecting otherwise subvertical fractures and subvertical wells.
\end{abstract}

Keywords Faults $\cdot$ Fractured rocks $\cdot$ Groundwater flow $\cdot$ Connectivity $\cdot$ Ireland

\section{Introduction}

Groundwater is critical for sustaining ecosystems and communities across the island of Ireland. It accounts for over $25 \%$ of Ireland's drinking water supply, is an important source of water for food and industrial processing (Clabby et al. 2008), and has significant potential as a low enthalpy geothermal energy source (Blake et al. 2016, 2021, this issue). By far

This article is part of the topical collection "Progress in fractured-rock hydrogeology"

J. P. Moore

john.moore@ucdconnect.ie

$1 \quad$ Fault Analysis Group and Irish Centre for Research in Applied Geosciences (iCRAG), UCD School of Earth Sciences, University College Dublin, Belfield, Dublin 4, Ireland

2 Arup, 50 Ringsend Road, Dublin 4, Ireland the most important source of groundwater is from hard fractured Carboniferous limestone bedrocks which, from studies in Ireland and the UK, have very low primary porosity (ca. 1\% or less), with effective porosity and flow mainly dependent upon faulting, fracturing and karst (e.g. Daly 1995; Allen et al. 1997; Abesser et al. 2005; Fitzsimons et al. 2005; Ball 2007; Clabby et al. 2008). These groundwater systems are, therefore, equivalent to fissure system aquifers in limestones (see Motyka 1998) and type 1 naturally fractured reservoirs encountered within petroleum systems (Nelson 2001; Narr et al. 2006), both of which are characterised by porosity and permeability that is dominated by fractures and karstified (i.e. dissolution-enhanced) fractures. From the analysis of more than 120 outcrop, quarry, mine and cave locations (Fig. 1), dominantly within aerially extensive Carboniferous limestone-shale sequences but also in younger and older non-limestones (Fig. 1; Moore and Walsh 2013), this report briefly describes the youngest fracture systems affecting groundwater flow in Ireland, i.e. Cenozoic faults and recently 


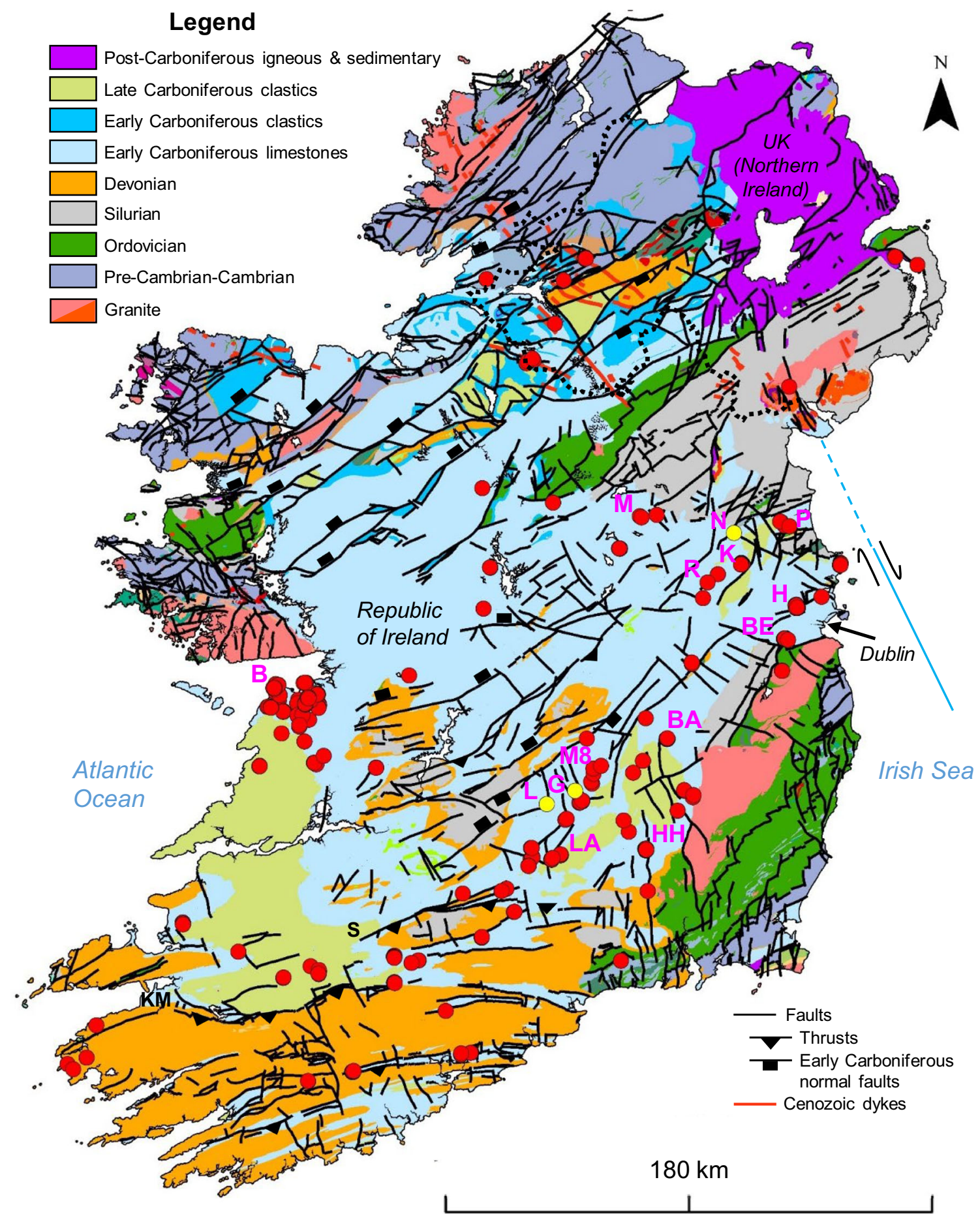

Fig. 1 Geological map of the island of Ireland showing the principal bedrock sequences, faults and dykes (Geological Survey Ireland 2018). Locations of outcrops/quarries (red dots) and mines (yellow dots) included in this study, with localities referred to in the text labelled (pink), as follows: The Burren outcrop and caves (B), Ballyadams Quarry (BA), Belgard Quarry (BE), Huntstown Quarry (H), Kilmessan Quarry (K), Laffansbridge Quarry (LA), M8 Quarry (M8), Platin Quarry (P), Rathmolyon Quarry (R), The Murrens Quarry (M), Navan mine (N)
Galmoy mine (G) and Lisheen mine (L). The Killarney-Mallow thrust $(\mathrm{KM})$ and the Slievenamuck thrust (S) are distinguished, with the former coincident with the northern boundary of the main Variscan fold and thrust belt. The general location of the Codling fault within the Irish Sea is shown (blue line and black slip indicators; see Cooper et al. 2012; Anderson et al. 2018). The border between the Rep. of Ireland and the UK (Northern Ireland) is shown (black-dotted line) 
formed joints. The principal objective is to show that the nature, geometry and scaling of these fracture systems, which are related to deformation conditions, host-rock sequence and preexisting structure, exercise fundamental controls on their differing impacts on groundwater flow. A secondary objective is to highlight findings that are relevant to both the conceptualisation (flow magnitude and pathways) and numerical modelling of flow within fracture system aquifers, for groundwater resource and contaminant transport studies (e.g. Comte et al. 2012; Moore and Walsh 2013; Anderson et al. 2016; Martel 2017; Ofterdinger et al. 2019; Medici et al. 2019a, b).

In Ireland there are many different types of faults and fractures that are important for groundwater flow, the main ones of which are represented schematically in Fig. 2. The NEtrending early Carboniferous normal faults transecting Ireland (Fig. 1) are sealing structures to groundwater flow (Moore and Walsh 2013), due to a number of factors including their displacement, burial history, fault rocks (e.g. shale-rich gouge and smear, stylolitisation) and vein content. Their sealing nature is sometimes reflected in across-fault differences of groundwater head in mines and quarries, and is in marked contrast to the flow effects of later Cenozoic faults that are more conventional permeability enhancing structures within limestones (Moore and Walsh 2013; Bauer et al. 2016; Ferrill and Morris 2003; Walsh et al. 2018; Ferrill et al. 2020). Variscan (late Carboniferous) NNW- to NNEtrending veins and NE- and NW-trending strike-slip faults are characteristically vein filled and are therefore also intrinsically sealing to groundwater flow (Moore and Walsh 2013). The most important departure from the sealing behaviour of these Carboniferous structures is, however, their susceptibility to the dissolution of adjacent host rock limestones or calcite vein infills (Moore and Walsh 2013; Walsh et al. 2019; Schuler et al. 2020a). In Ireland this limestone dissolution is usually very recent and uplift-related, leading to the generation of karst-related groundwater flow systems characterised by complex networks of conduits and caves that are strongly controlled by preexisting, and originally sealing, structures and bedding planes (Drew 1990; Moore and Walsh 2013; Moore and Walsh 2019). For example, clustered arrays of NNE-trending calcite veins, up to ca. $0.5 \mathrm{~m}$ thick, have provided the locus for highly directional karst networks controlling groundwater flow within the classic karst region of The Burren in the west of Ireland (Moore and Walsh 2013; Drew 2018; Moore and Walsh 2019; Walsh et al. 2019). Although all of the foregoing fault and fracture systems have implications for groundwater flow in Ireland (Moore and Walsh 2013), this study concentrates on Cenozoic and recent fracture systems in an attempt to define generic findings that can be applied in other areas.

This report describes some of the quantitative characteristics of the most recent fracture systems localising groundwater flow in Ireland, Cenozoic strike-slip faults and stress-release (i.e. unloading) related joints (Fig. 2). These fractures are often
Fig. 2 Schematic diagram showing the main post-Devonian fault and fracture systems controlling groundwater flow in Ireland (Moore and Walsh 2013). Legend lists structures in stratigraphic age, with multiple Variscan and Cenozoic structures, for simplicity, given the same relative age. Cenozoic strike-slip faults and veins are given slightly different colours, with the hybrid veins representing mixed extension and shear structures mainly generated in association with strike-slip fault bends or steps. Joints are developed in the uppermost 5-10 $\mathrm{m}$, with higher densities of joints at shallow depths reflecting greater unloading and decoupling along bedding surfaces (detail not shown) and with deeper extending joints often spatially developed adjacent to preexisting major structures (e.g. faults and veins)

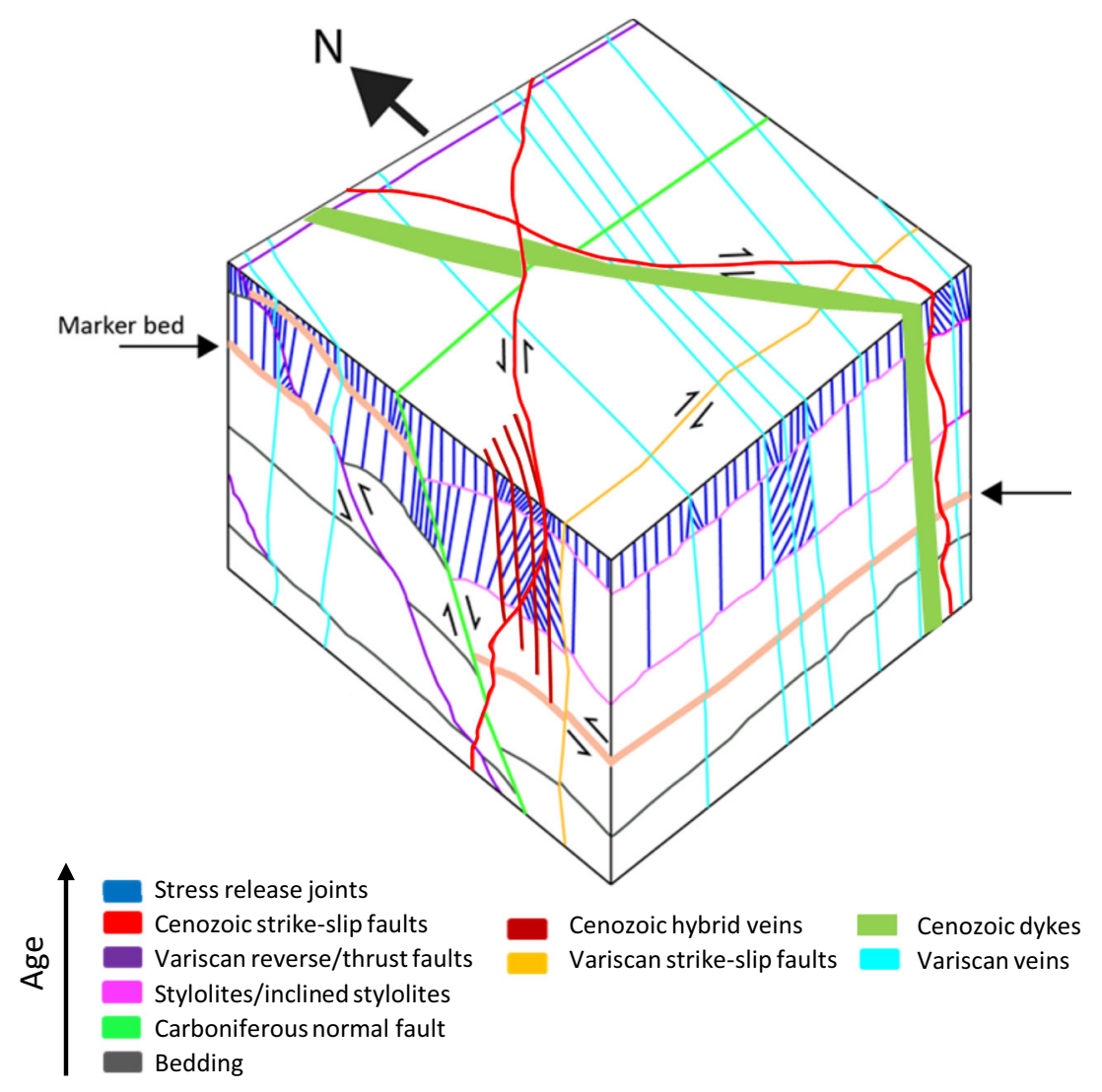


intrinsically conductive, principally because they formed recently and at relatively low confining depths $(<$ ca. $1 \mathrm{~km}$; Moore and Walsh 2013). Joints are a ubiquitous feature of shallow bedrock in Ireland and Cenozoic faults are very commonly developed particularly within the southern and eastern parts of the island. Together they often represent the most important structurally controlled conduits for groundwater flow in the shallow $(<10-30 \mathrm{~m})$ and deeper subsurface, with major contributions from joints and faults respectively. The conductive nature of these structures also means that they can be an important inceptor of karst, providing a further increase in their flow. Observations from Ireland's $\mathrm{Zn}-\mathrm{Pb}$ mines, for example, indicate that the Cenozoic faults are responsible for accentuated karst even at the intersections with otherwise sealed NE-oriented Lower Carboniferous normal faults (Moore and Walsh 2013). The geometrical properties of the Cenozoic faults and joints are conveniently defined in terms of end-member geometries of fracture systems defined by Odling et al. (1999), with faults forming nonstratabound systems characterised by scale independent and highly clustered fractures, and joints forming stratabound systems showing scale-dependent properties that are strongly controlled by individual beds (Figs. 2 and 3a). In this study, it is suggested that their contrasting mechanical origins and the associated fundamental difference in fracture type and scaling is responsible for the differing impact of these structures on groundwater flow within bedrock limestones that would otherwise have negligible effective primary porosity. Within these fractured aquifers of Ireland, Cenozoic faults represent the most important target for sustainable flows and both faults and joints provide significant groundwater storage, particularly when karstified. Since this duality of behaviour may also be replicated in other groundwater systems affected by equivalent fault/ fracture networks, it is suggested that the findings of this study have relevance for practical applications including groundwater resource and contaminant transport studies (e.g. Comte et al. 2012; Moore and Walsh 2013; Anderson et al. 2016; Martel 2017; Ofterdinger et al. 2019; Medici et al. 2019a and b).

\section{Geological analysis}

\section{Methodology}

This study mainly combines field-based analysis of the structural controls on groundwater flow at outcrop, cave, quarry and mine localities, with the analysis of flow response from groundwater levels and flow data within mines and quarries. Structural analysis involved the following steps:

- Quantitative analysis of the geometry, scaling and kinematic relationships of different fault and fracture systems. This included definition of size and spatial distributions of
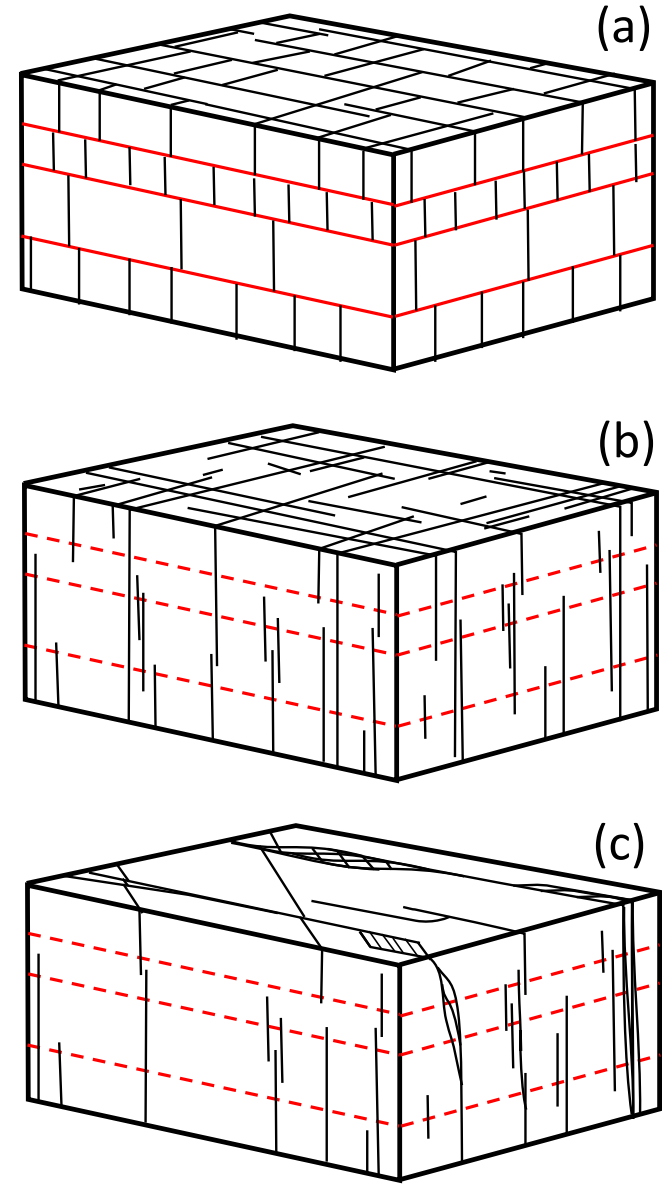

Fig. 3 Schematic diagram showing the major features of a stratabound and b nonstratabound extension fracture systems and $\mathbf{c}$ nonstratabound fault (i.e. shear fracture) systems. a Stratabound fracture systems are largely confined to individual beds (or mechanical units), with the size ranges and spacing of fractures controlled by bed thickness: equivalent to stressrelease joints in Ireland. b Nonstratabound extension fracture systems have a broader range of fracture sizes which cross-cut bedding and have scaleindependent and clustered geometries: Variscan veins have similar scaling characteristics. c Nonstratabound strike-slip fault systems with strongly clustered and scale-independent geometries, characterised by damage zone faults and extension fractures (including veins), particularly in association with bends and relays: Cenozoic strike-slip faults in Ireland have similar scaling properties. Parts a and b are modified after Odling et al. (1999)

different faults/fractures from both line samples (e.g 1D) and map samples (i.e. 2D), using conventional orientation and spatial analysis techniques (including fault-fracture intensities and spacing), and a variety of measures and techniques for fault/fracture size analysis (e.g. displacement, aperture, map lengths, vertical persistence)

- Examination of fault rocks and fracture infills (usually calcite), and qualitative consideration of their likely impact on flowe.g. visual indicators of flow: see next subsection, presence of insoluble clay concentrates (i.e. restites), vein fill, vuggy infill

- Analysis of quantitative measures (i.e. vertical persistence, spacing, stratabound or nonstratabound scaling) of the impact of lithological sequence (e.g. mechanical stratigraphy, bed dips) on fault/fracture system geometry and scaling. 

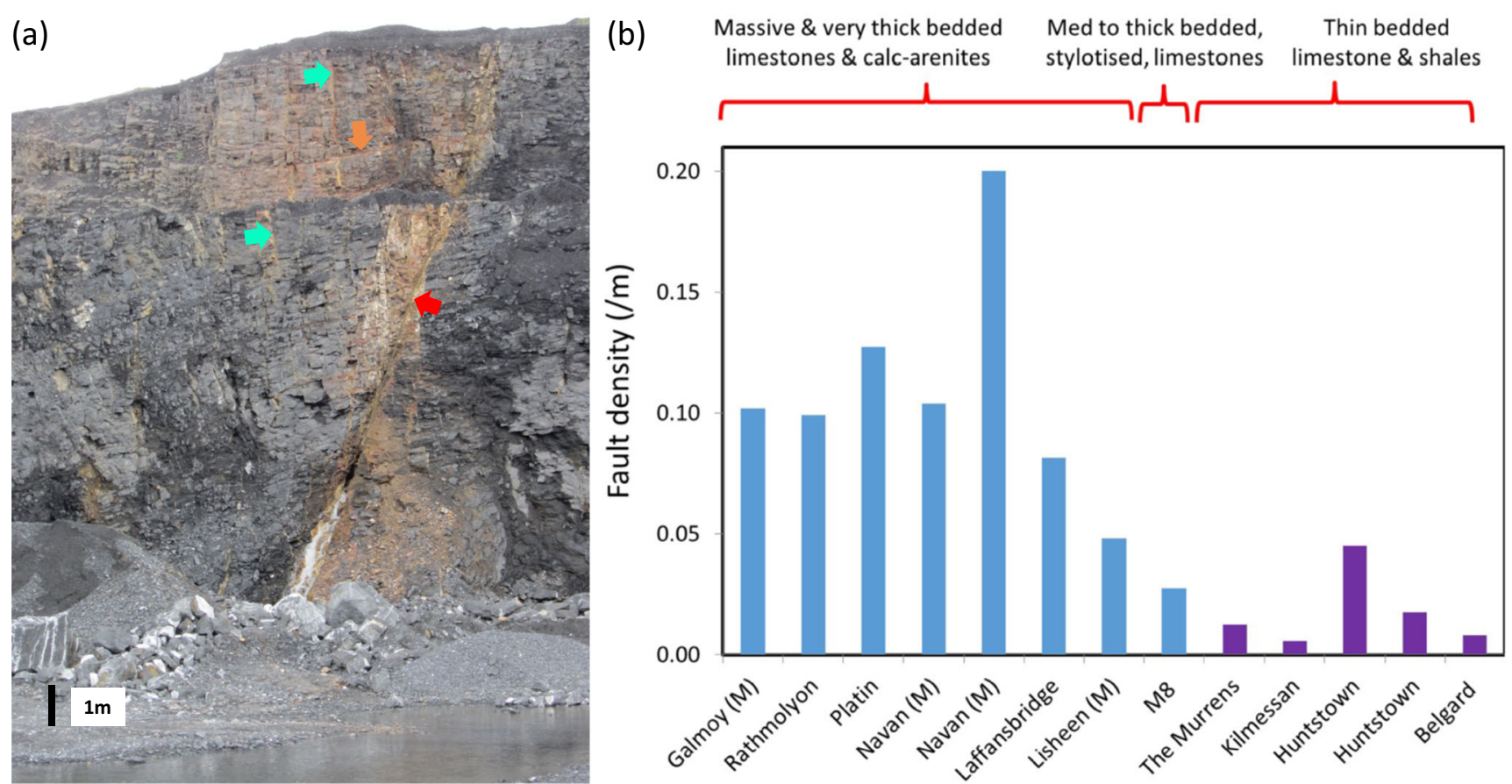

Fig. 4 a Cenozoic strike-slip fault (red arrow) with a cavity and groundwater flow localised on a fault bend at Huntstown Quarry, Dublin. Conductive fractures within the fault damage zone have reddish orange discolouration arising from localised groundwater flow. Steep fractures (e.g. green arrows) tend to have different strike and dip to the fault, whereas shallow dipping fractures are usually bedding parallel (e.g.

Consideration of groundwater flow involved the following:

- Assessment of groundwater flow from visual indicators of groundwater flow, including karst-related dissolution, karst sediment infill and iron-oxide staining

- Review and analysis of available groundwater level and flow data (usually from either quarry or mine data) in relation to potential geological controls on flow for individual case studies

- Application of bulk permeability $(k)$ and porosity $(p)$ plot for the computation of groundwater parameters from fracture aperture and spacing data

Application of these structural and groundwater methodologies underpins the main conclusions advanced from this and previous related studies (e.g. Moore and Walsh 2013).

\section{Results}

\section{Cenozoic faults}

Cenozoic strike-slip faults occur in conjugate pairs of approximately NNW- and NE-trending faults, which are dextral and sinistral respectively (Fig. 2; Cooper et al. 2012; Anderson orange arrow). b Density of Cenozoic strike-slip faults in different lithological sequences, measured as number of faults per metre along ca. 100$\mathrm{m}$-long sections. Data are mostly from quarry (Q) and mine (M) exposures and two are from mine maps (Galmoy and Navan): thickly bedded massive limestone sequences (blue) and argillaceous limestone and shale sequences (purple) are distinguished et al. 2018). This configuration has been attributed to approximately N-S Alpine shortening accommodated by sinistral displacements on older NE-striking Carboniferous normal faults and the widespread development of smaller NNWtrending dextral strike-slip faults (Cooper et al. 2012). The prevalence of dextral faults is attributed to the generation of numerous newly formed arrays of faults in the absence of large preexisting faults that are NW-NNW-trending (Anderson 2013). The pervasive nature of dextral faults relative to the more localized and reactivated sinistral faults, and their recent formation at shallow depths, means that these structures often have a major impact on groundwater flow (Moore and Walsh 2013). They are usually characterised by spatial distributions which are intrinsically clustered on a range of scales, with nonstratabound spatial distributions in which larger-scale faults, with bigger displacements, cut and displace different mechanical layers (Figs. 2 and 3c). Whilst definition of the precise scaling properties of the displacement populations of these strike-slip faults is not possible, because of the difficulty of accurately measuring strike-slip displacements offsetting subhorizontal beds, their spatial distributions and significant displacement ranges suggest that, like many tectonic fault systems, they have power-law, scaleindependent characteristics (e.g. Walsh et al. 1991, 2003; Odling et al. 1999). The densities of Cenozoic strike-slip 
faults, measured as the number of faults per metre on faultperpendicular sample lines (Fig. 4b), ranges over an order of magnitude, with densities varying with fault size (e.g. displacement and length) and the mechanical properties of the host rock (Figs. 3 and 4b). Higher fault densities occur within thickly bedded and massive (i.e. unbedded) limestones that are relatively brittle, whilst lower densities occur within argillaceous limestone and shale sequences within which deformation is more discrete and localised (Fig. 4b), partly because of the ductile nature of the host rock shales. The localisation of Cenozoic faults along or adjacent to preexisting structures such as suitably oriented normal faults and Variscan veins (e.g. Fig. 5b), can also promote the formation of higher fracture densities, with quarry mapping indicating that the geometry of reactivation-related high density systems of Cenozoic faults is strongly influenced by the configuration of preexisting structures. On a regional scale there is a westward decline in deformation intensity of Cenozoic strike-slip faults across Ireland, with faults in the west forming progressively lower density systems that are less vertically persistent, so that within The Burren, in the far west of Ireland, they appear to be absent. By contrast, these faults are more numerous in the east and can have much larger displacements, with up to $9 \mathrm{~km}$ dextral displacement on the NNW-trending Codling fault in the Irish Sea (Cooper et al. 2012; Fig. 1). These regional changes are attributed to an eastward increase in Alpinerelated $\mathrm{N}-\mathrm{S}$ compressional deformation arising from plate reconstructions of NW Europe (Dewey and Windley 1988).

Quantitative analysis of Cenozoic strike-slip faults indicates that their geometry and nature vary with lithological sequence and with spatial controls such as depth, regional variations in deformation style and intensity, and the presence of preexisting structures. Strike-slip faults are accompanied by fault-related damage, including intense fracturing and vein networks, the distribution of which can be very heterogeneously developed and are often controlled by fault intersections and along-fault complexities such as bends and steps (Figs. 2, 3c and 4a). Individual faults are relatively uncemented, often having vuggy vein infills, due to their formation and burial at lower confining pressures than their Carboniferous equivalents. As a consequence, Cenozoic faults yield the highest and most sustainable flows in Ireland (Moore and Walsh 2013). One such fault, shown in Fig. 4a, is responsible for most of the inflow, of up to $7,000 \mathrm{~m}^{3} /$ day, into one of

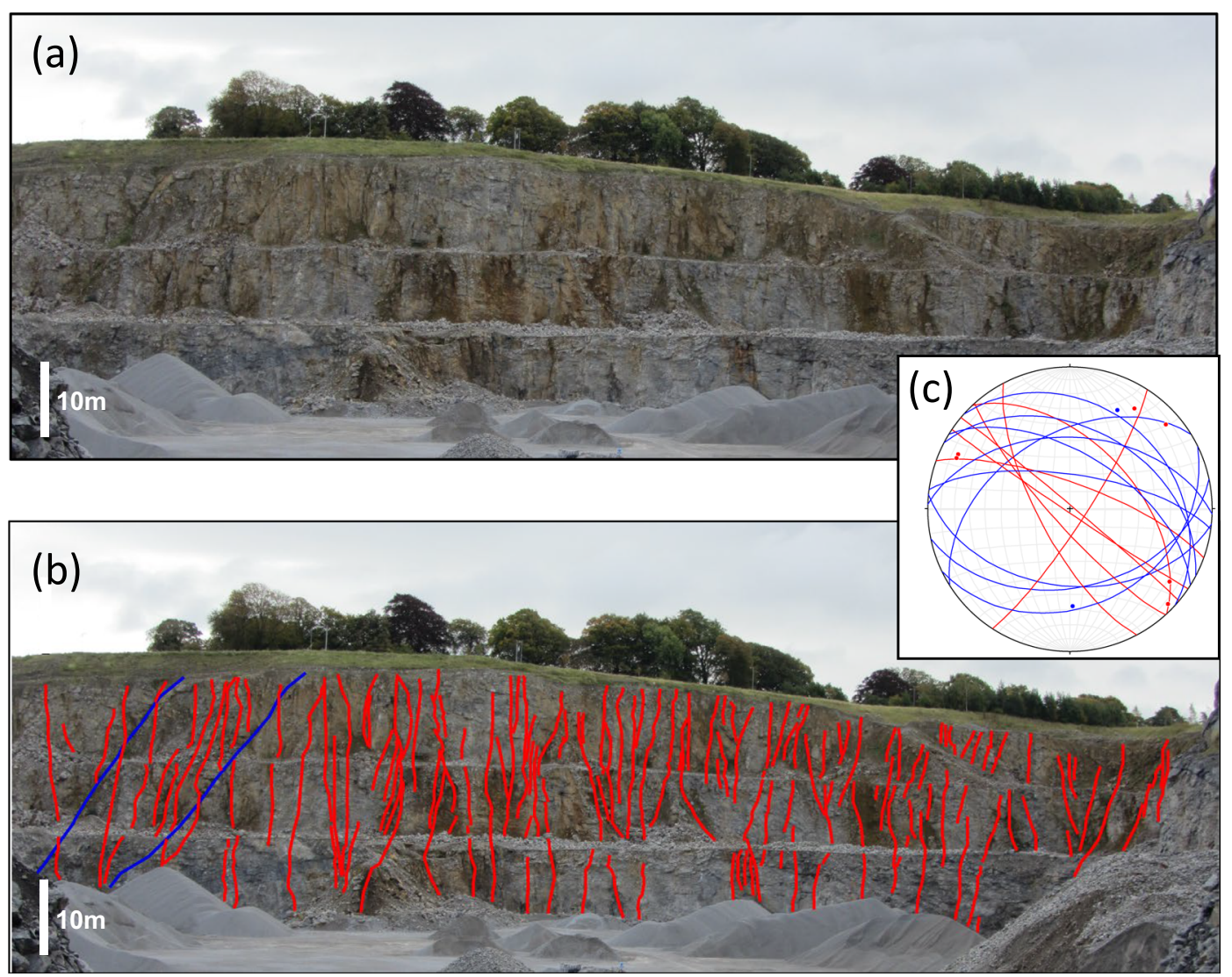

Fig. 5 a Working face at Rathmolyon Quarry (viewing ESE)) within poorly bedded (i.e. massive) Waulsortian Limestones (see Fig. 1 for location). b Interpretation of a showing Lower Carboniferous normal faults (blue) and high-density system of Cenozoic strike-slip faults (red): the vertical impersistence of some Cenozoic faults arises from the difficulty of tracking individual faults across three working benches. c A lower hemisphere stereographic projection (plotted using the Stereonet software package of Allmendinger et al. 2012) showing the surfaces and striations of Lower Carboniferous normal faults (blue) and Cenozoic strike-slip faults (red) 
the biggest limestone quarries in Ireland (i.e. Huntstown quarry in north Dublin; Fig. 1). This fault has an estimated strike-slip displacement of less than ca. $20 \mathrm{~m}$ and is the preeminent conductive structure in a quarry which is bounded by E-W trending Lower Carboniferous normal faults (with ca. 200-m vertical displacement). On the basis of groundwater levels from monitoring wells, the earlier normal faults contribute to groundwater compartmentalisation, principally because of their displacements and fault rock attributes: these faults are not, however, the subject of this report. The Cenozoic strikeslip fault, however, shows the characteristic pink veining and high densities of associated damage zone vuggy fractures of most Cenozoic faults, with reddish-brown discolouration of surrounding rock due to accentuated fluid flow (Fig. 4a). Outcrop studies show that localised zones of accentuated aperture and flow are generated by strike-slip movements along vertical and horizontal releasing fault bends (e.g. Fig. 4a; Moore and Walsh 2013), orientations that are kinematically sensible insofar as they are approximately perpendicular to strike-slip displacements (i.e. vertical) or are localised along subhorizontal bed interfaces (e.g. Walsh et al. 1999; Roche et al. 2021). These dilations combined with karstification mean that relatively small displacement (m-scale) faults can strongly localise high and sustainable groundwater flows. For example, within Lisheen $\mathrm{Zn}-\mathrm{Pb}$ mine (see Fig. 1 for location), a ca. 10-m displacement NNW-trending dextral strike-slip fault (referred to as the F2-F3 fault in Fusciardi et al. 2003) produced over $100,000 \mathrm{~m}^{3}$ /day when intercepted in 1999 , only declining to $22,000 \mathrm{~m}^{3} /$ day on mine closure in December 2015 (J. Guven and B. Quaid, Vedanta Ireland, personal communication, 2015). These high, sustainable flow rates are attributable to fractures and associated karst because the host rock Carboniferous limestones have very low primary porosity and any potentially porous surficial deposits are relatively thin.

\section{Joints}

Joints are the youngest and most ubiquitous structure in the fractured bedrocks of Ireland and they are always uncemented extension fractures, as opposed to shear fractures (Fig. 6). Joint systems are intrinsically stratabound (Figs. 2 and 3a), displaying scaling properties which vary with layer/ mechanical unit thickness (Price 1966; Gillespie et al. 2001; Mandl 2005; Schöpfer et al. 2011). This scaling behaviour can, however, be obscured by increases in joint apertures and densities (i.e. frequencies) towards the bedrock surface, features that are attributed to the unloading and stress-release related origin of the joints (Moore and Walsh 2013). Significantly, these depth-related changes are also responsible for increases in porosity and permeability towards the surface (see the next section).
The geometrical characteristics of joint systems are very different from those of Cenozoic strike-slip faults, insofar as they often display periodic/regular spatial and stratabound density variations rather than the highly clustered nonstratabound spatial distributions of strike-slip faults (Figs. 2 and 3; Odling et al. 1999; Gillespie et al. 2001). This fundamental difference arises from the importance of bed (i.e. strata) boundaries as decoupling (delamination) surfaces at the very low prevailing confining pressures and fluid pressures characteristic of stress-release structures often within the top $10 \mathrm{~m}$ of bedrock: in this context, the term 'bed' is used to refer to individual mechanical units, which on closer examination may, however, have smaller scale 'interbeds' which do not represent mechanical decoupling surfaces. High densities of near-surface stress-release joints provide a basis for hydrogeological characterisation of 'epikarst' (Jones et al. 2013; Drew 2018), the zone of enhanced fracturing and dissolution seen within shallow limestone bedrocks ( $<30 \mathrm{~m})$. Such high densities also influence the nature of the overlying ( $\mathrm{m}$-scale) transition zone between the epikarst and subsoil (e.g. Fitzsimons et al. 2005; Kelly et al. 2015; GSI 2019), an issue which is discussed further in section 'Discussion'.

The stratabound nature of joint spacing is defined by inverse trends between bed thickness and joint density (Fig. 6c), with the scatter of data arising from other controlling factors, including proximity to bedrock surface, the equivalent of depth. This is illustrated in Fig. $6 \mathrm{c}$ for a limestone sequence in which layers approaching the bedrock surface have higher densities compared to similar thickness beds at greater depths. Joint densities show a rapid (almost exponential) decrease with depth down to $9 \mathrm{~m}$ (Fig. 6d; values were computed immediately adjacent to the vertical red arrow in Fig. 6a), supporting the stress release origin of these structures. Variations in the decline in joint densities with depth arise for a number of reasons such as the irregular nature of the cliff face, mechanical stratigraphy and the presence of preexisting structures (Fig. 6). For example, the return to higher density of joints at greater depths highlighted on Fig. 6d (blue arrow) corresponds with the only limestone bed in the section bounded by shale layers (Fig. 6b, blue arrow) and suggests that the reduced interfacial friction due to the interbedded shale (Mandl 2005; Schöpfer et al. 2011) has resulted in the increased joint densities. Greater interfacial slip can also result in accentuated groundwater flow as is evident from the iron oxide-stained seepages from the limestone-shale interface below the lower shale bed (Fig. 6a and immediately below the blue arrow in Fig. 6b). The bedrock surface also cuts down through beds so that they have a lateral edge (Fig. 6a,b). This is highlighted by profiles showing the left-to-right changes of joint spacing along individual beds (coloured lines in Fig. 6b) as the cumulative number with distance from the bedrock surface (Fig. 6e). All three profiles show steeper slopes in proximity to the bedrock surface, a feature which highlights 
Fig. 6 a Joints developed within the limestones in Ballyadams Quarry, Kildare (see Fig. 1 for location), with b showing inset (green box). Joints are usually newly localised structures but at depths of several metres below the bedrock surface the longer joints are localised along enechelon veins associated with Cenozoic strike-slip faulting. Vertical red arrow in a shows path along which joint densities were measured for each of 25 beds (measured in $3.7 \mathrm{~m}$ long sections), and plotted against bed thickness (c) and against depth (d). b-d The blue arrow identifies a shale-bounded,

high joint density limestone bed that is discussed further in the text. The very high densities in beds highlighted (c) are affected by near-surface jointing (blue envelope) to a greater extent relative to beds of similar thickness at greater depths. e A plot of cumulative number of joint spacings with distance taken from left to right along the different coloured line samples shown on the inset photo (b)

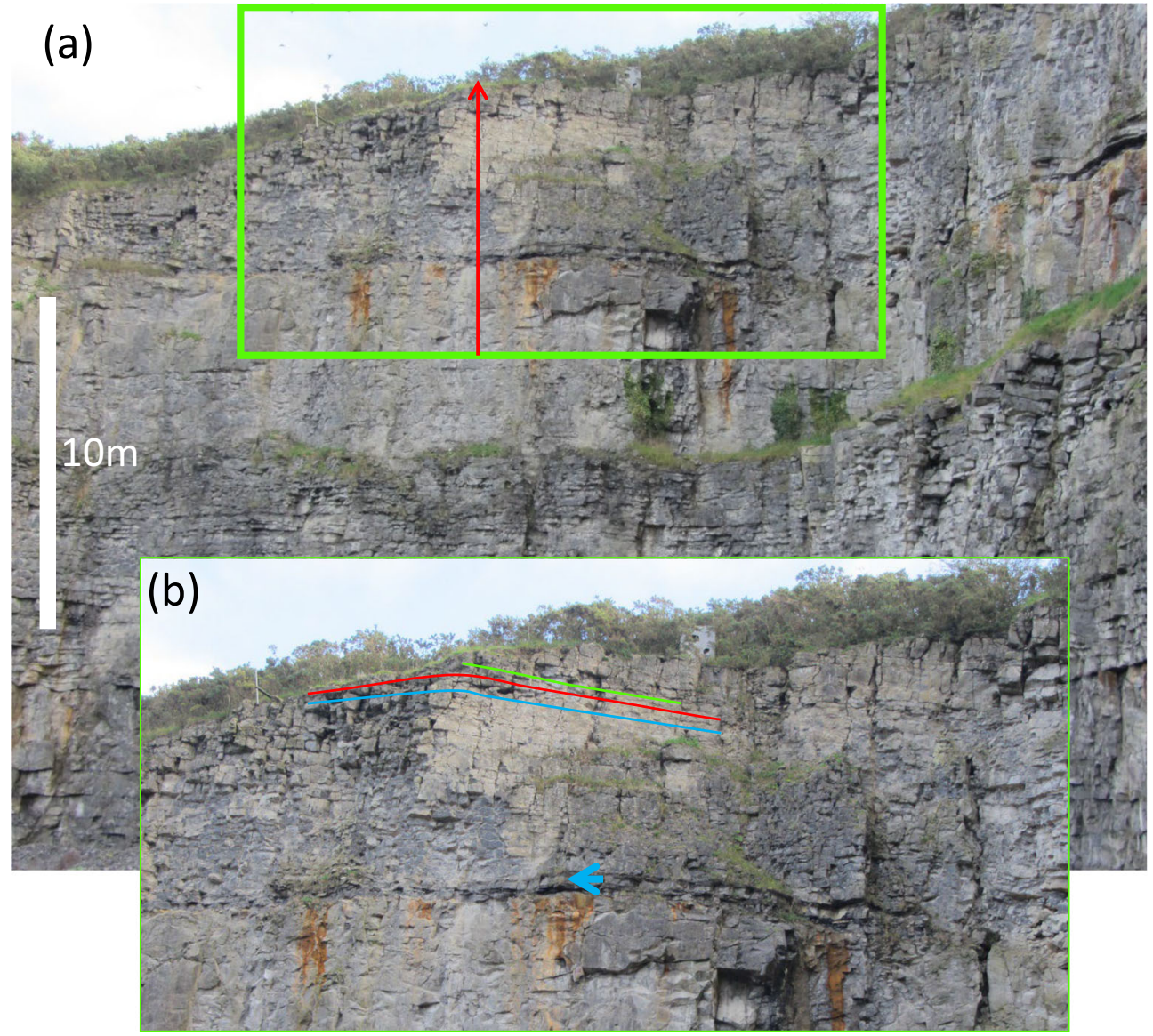

(c)

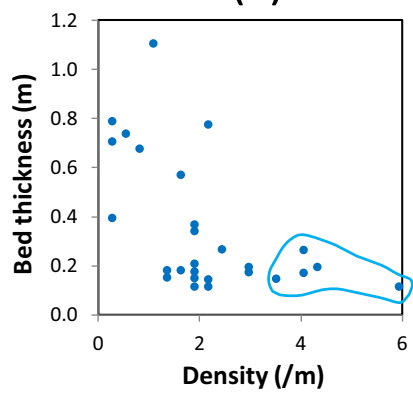

(d)

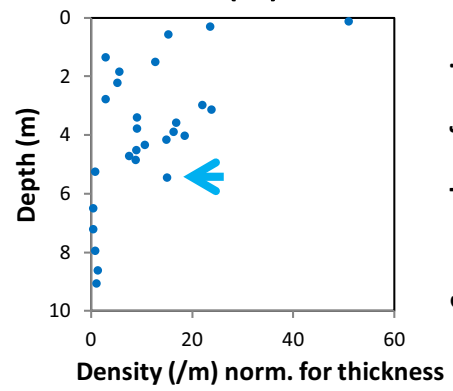

(e)

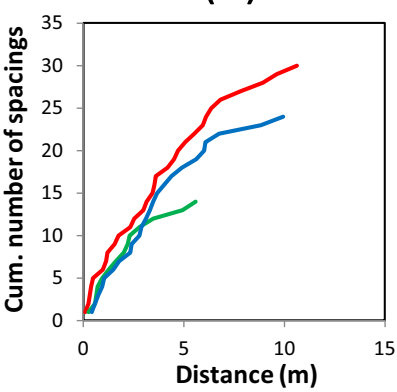

the lateral increase in joint density towards that surface. These lateral and vertical increases in joint densities form a highly fractured shallow bedrock and transition zone generally within ca. $3 \mathrm{~m}$ below the bedrock surface but sometimes extending to below $10 \mathrm{~m}$ (Fig. 6). The variable depths arise from a combination of factors including the mechanical stratigraphy, the presence and nature of preexisting structures, and the geometry and rugosity of the bedrock surface (e.g. arising from karstification). Whatever the precise form of these density changes, accentuated fracturing and karstification of fractures in proximity of limestone bedrock surfaces (Fig. 6) is an important contributor to the increased chances of obtaining a water strike and more sustainable flows at shallower depths (suggested by the transmissivity curve in Fig. 7), a feature which is returned to within the next section and section 'Discussion'.

\section{Estimating groundwater flow parameters}

Groundwater flows and levels are used to parameterise the flow connectivity of NNW-N-NNE-trending Cenozoic strike-slip faults and associated karst. This is illustrated, in particular, for a system of Cenozoic strike-slip faults encountered along the $\mathrm{K}$ Zone of Galmoy $\mathrm{Zn}-\mathrm{Pb}$ mineral deposit, which lies within the northern, hanging wall (and 


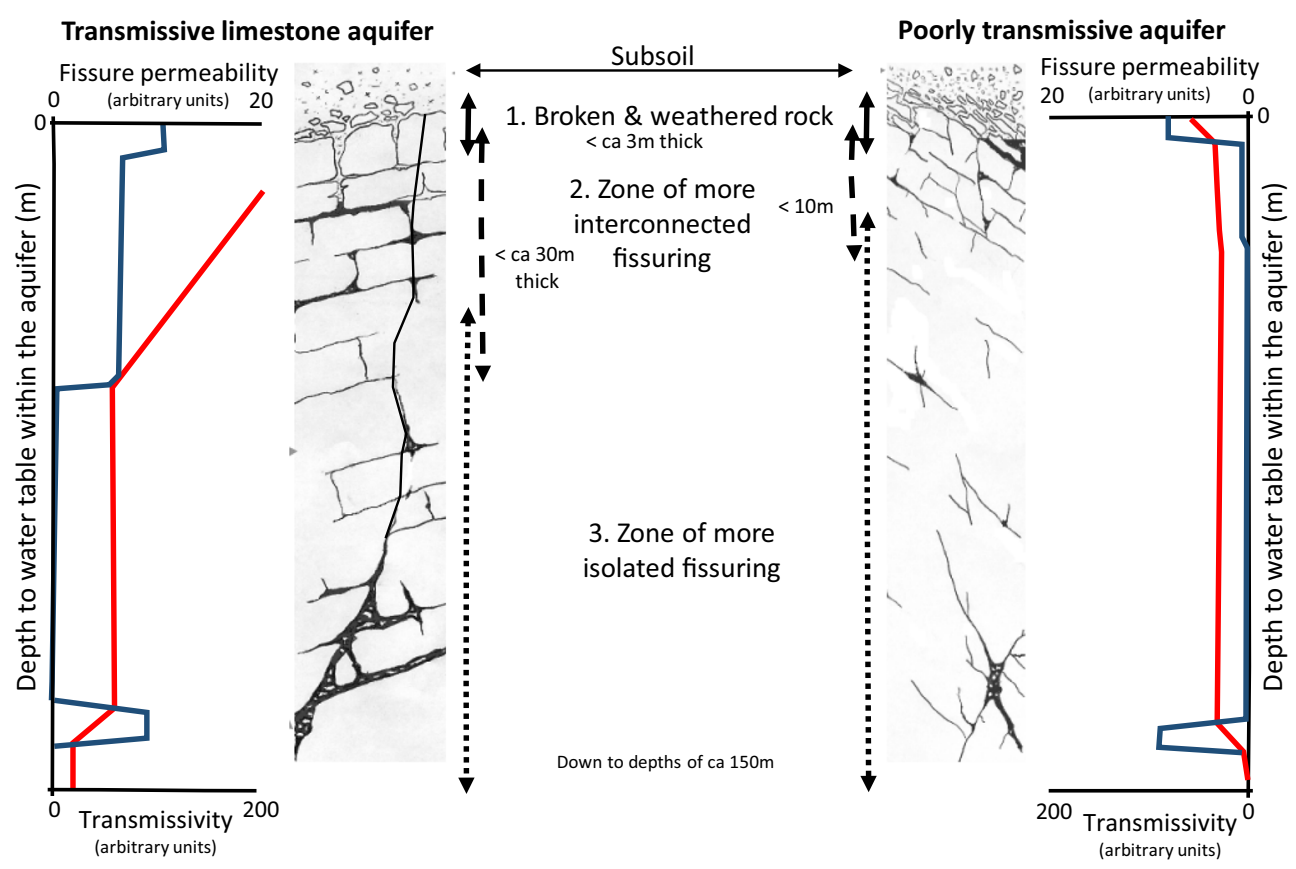

Fig. 7 A conceptual model of transmissivity (red) and fissure permeability (blue) curves with depth in two hypothetical bedrock aquifers in Ireland (from Fitzsimons et al. 2005). a A generally transmissive bedded limestone aquifer with shallow depth joints which become less interconnected with depth, eventually giving way to more isolated open fractures particularly adjacent to more deeply rooted faults, as indicated by the

downthrown) side of a ca. 200-m displacement ENE-trending Carboniferous normal fault (G fault; Fig. 8a; Lowther et al. 2003). Mine dewatering has shown that this normal fault compartmentalises groundwater (P. McDermott, Lundin Galmoy Mines, personal communication, 2017 and 2021), an issue which is beyond the scope of this report. High densities of NNW-N-NNE trending faults in the $\mathrm{CW}$ and $\mathrm{K}$ zones are mainly Cenozoic strike-slip faults, with the larger (i.e. longer) faults being NNW-trending dextral structures (Fig. 8a,b; C. Bonson personal communication, 2012). Underground flows intercepted on Cenozoic faults are extremely variable, with individual faults displaying very heterogeneous flow rate variations (from zero to very high) on less than decameter scale. This heterogeneity is attributed to a combination of structural complexity compounded by groundwater-related dissolution and karstification - for example, along-fault structural complexity produces heterogeneous development of voids, particularly developed as elongated voids on bends (Fig. 4a; Moore and Walsh 2013), which are often connected with kinematically associated fractures that are more dilational and more northerly trending (Figs. 4a and 8). The orientations of these bends or relays would suggest that associated zones of enhanced porosity and permeability would predominantly be vertical or horizontal (e.g. Walsh et al. 1999; Roche et al. 2021). The heterogeneity of voids and associated porosity along these faults and fracture systems is accentuated by karstification within the ca. 100-m sequence overlying the through-going structure. Karst-related dissolution occurs along structures and bedding planes, with more pervasive karst at shallow depths of less than $30 \mathrm{~m}$. b A poorly transmissive aquifer typical of interbedded limestone and shale sequences in which connected fractures are restricted to within ca. $10 \mathrm{~m}$, and in particular $3 \mathrm{~m}$, of the bedrock surface

deposit. This is consistent with evidence from the deeper Lisheen Mine, 13-km-long strike to the SW, indicating that accentuated karst along Cenozoic faults is mainly restricted to the depths of less than ca. $150 \mathrm{~m}$ within the same sequence of massive limestones (i.e. with no shale interbeds) that overlie both deposits (a sequence referred to as Waulsortian limestones; Doyle et al. 1992; Fusciardi et al. 2003).

At Galmoy, the combination of higher densities of variably oriented Cenozoic faults and associated fractures provides a system which is connected laterally and vertically (Figs. 4 and 8a,b). Map evidence of geometrical connectivity from decametre to hundreds of metres scale is very clear (Fig. 8), whilst vertical connectivity is promoted by dilations along vertical bends and accentuated dissolution, which may even be promoted by sulphuric acid derived from underlying sulphides, muddy limestones and shales (e.g. Schuler et al. 2020a). The importance of accentuated karst along the main Cenozoic faults in the CW Zone (Fig. 8a) is reflected in NNW (fault parallel) topographic depressions at surface (Fig. 8a,d), a feature which is consistent with the rapid (ca. 3 days) response to rainfall events in the mine (C. Bonson personal communication, 2012; B. Balding and P. McDermott, Lundin Galmoy Mines, personal communication, 2012 and 2021). A similar response to rainfall events is also observed along the F2-F3 fault at Lisheen, which from its intersection with the mine access road at a depth of ca. $100 \mathrm{~m}$ provides high sustainable flows over the lifetime of 


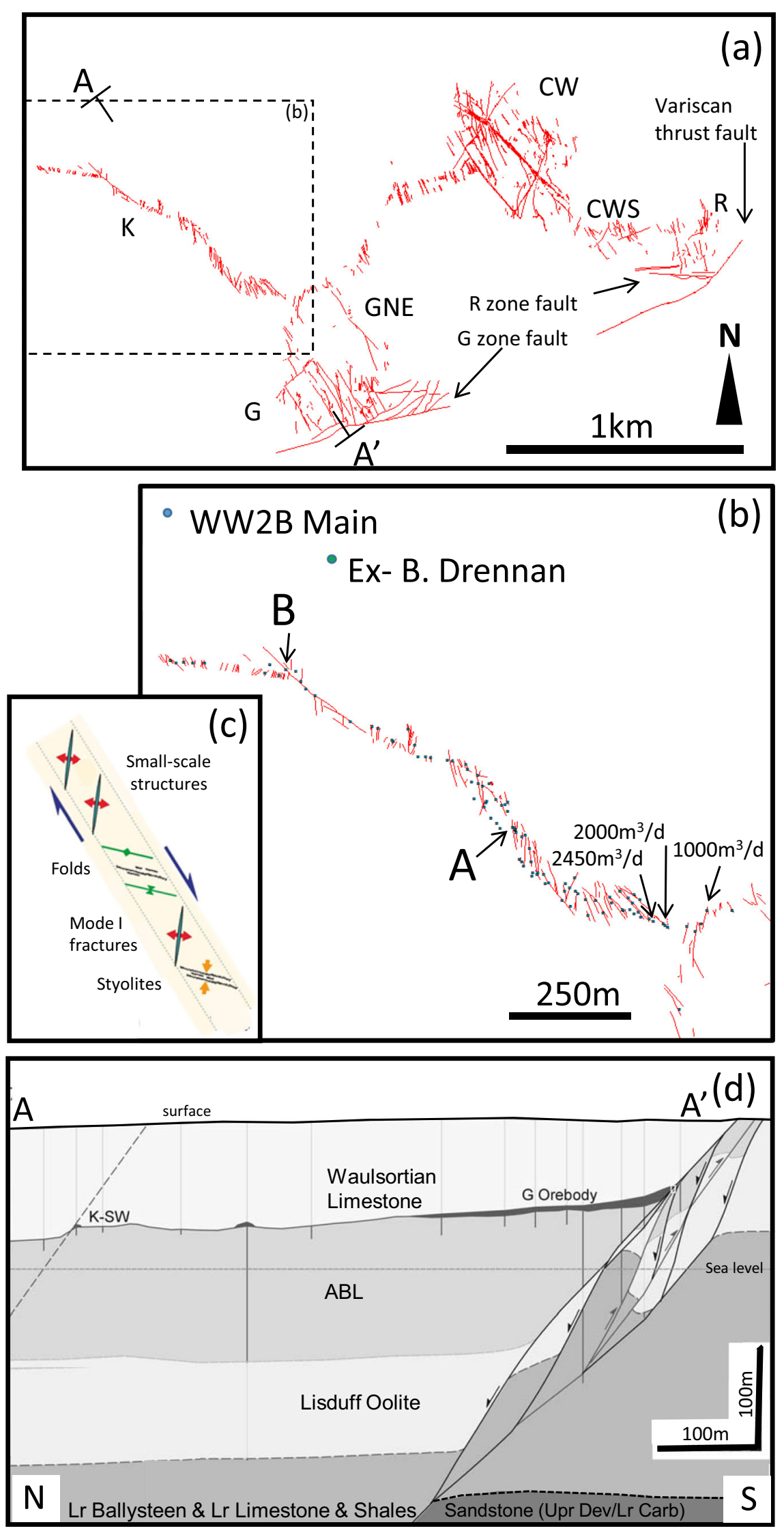


4 Fig. 8 a-b Maps of faults at base Waulsortian Limestone within the entire Galmoy Mine and the K Zone mine roadway, respectively. Flow points (blue) on individual and clusters of Cenozoic strike-slip faults intercepted during mining of the $\mathrm{K}$ Zone, for which monthly flow timeseries was recorded, are shown (b) together with three flow values labelled that are some of the largest flows intercepted. The other flow points labelled are discussed in the text. The inset schematic diagram (c) shows the orientations of minor structures associated with dextral strike-slip faulting, including more northerly oriented dilatational fractures (Fossen 2010), together providing geometries consistent with NNW-N Cenozoic strike-slip faults mapped along the K Zone (C. Bonson personal communication, 2012) and in mines and quarries elsewhere in Ireland. d An cross-section from the $\mathrm{K}$ zone through to the $\mathrm{G}$ zone (see a), showing the $\mathrm{G}$ zone Early Carboniferous normal fault with its Variscan reactivation (C. Bonson personal communication, 2012). The sequence and dip of the fault is the same as at Lisheen Mine, $13 \mathrm{~km}$ to the west. The Lower Ballysteen and Argillaceous Bioclastic Limestone (ABL) are argillaceous limestone members bounding the limestone dominated Lisduff Oolite member, all within the Ballysteen Formation of the southern Irish Midlands (Archer et al. 1996). Vertical lines from the surface, with labels, are mineral exploratory boreholes

the mine (16 years). Along the Cenozoic fault within Huntstown quarry, by contrast, the lower densities of faults and fractures (Fig. 4b), as well as the reduced dissolution compared to limestone dominated sequences, results in more discrete faults (Fig. 4b) and smaller apertures (Fig. 4a). Nevertheless, evidence of vertical flow connectivity and a large catchment volume to the Huntstown fault (Fig. 4a) is provided by water from its cavity having temperatures that are significantly elevated above background groundwater temperatures (i.e. up to $16{ }^{\circ} \mathrm{C}$ rather than ca. $11{ }^{\circ} \mathrm{C}$; Blake 2016).

Flow connectivity within Galmoy mine fault system is indicated by the fact that flows intercepted within the mine at the beginning of the $\mathrm{K}$ Zone (Fig. 8b) caused drawdown over $1 \mathrm{~km}$ away, to the N-NNW, in the 30-m-deep Ex B Drennan well (Figs. 8b and 9). Smaller-scale flow connectivity in the same N-NNW direction is demonstrated by flow point A (Fig. 8b), which, when intercepted, caused a decline in flows at the start of the $\mathrm{K}$ Zone, while interception of flow point B caused silting up of the main pumping well (WW2B), $390 \mathrm{~m}$ to the N-NNW (Fig. 8b; P. McDermott, Lundin Galmoy Mines, personal communication, 2017). The best measures/parameters to represent the flow connectivity between $\mathrm{K}$ Zone flows and the resulting drawdown, via the complex system of Cenozoic faulting and associated karst, is the cumulative flow (the perturbation) over a specific period of time (and recharge; Fig. 9) and distance (Fig. 8b; Moore et al. 2019). The cumulative flow until a resulting drawdown response at Ex B Drennan well is estimated to be $10,829 \mathrm{~m}^{3}$ / day over a 7-month period, and the cumulative flow until a quasi steady state has been reached (from approximately Nov. 2007) is $247,934 \mathrm{~m}^{3}$ /day over a 59 -month period (Fig. 9). Given the depths (100-30 m below bedrock surface) and the lithology (i.e. massive limestones; Fig. 8d), the flow connectivity is likely to dominantly result from the Cenozoic strike-slip faults and related karstification: a secondary effect is, however, localized karst development at the base of the massive limestones (P. McDermott, Lundin Galmoy Mines, personal communication, 2017), a feature here attributed to karst inception at the intersection with karstified Cenozoic faults that are linked to the surface. The associated cumulative flows and drawdown could be used as targets for sustainable abstraction from the K Zone. Similar cumulative flows have been recorded on other Cenozoic strike-slip faults which generally represent the structures which most strongly localise groundwater flow and are therefore potential targets for groundwater supply. In this regard, the WNW-oriented horizontal K Zone mine roadway (Fig. 8a,b) represented a very efficient means of directly intercepting the higher and more sustainable flows from steep NNW-N trending Cenozoic faults compared to a vertical pumping well, a feature which reflects the strongly anisotropic and heterogeneous nature of the associated aquifer properties. This is considered later in section 'Discussion'.

By contrast with the complex, heterogeneous and scaleindependent nature of Cenozoic faults, the scale-bound nature of joint systems suggests that bed-scale groundwater parameters could, in principle, be defined analytically from empirically derived measures such as joint aperture (perpendicular opening) and spacing (perpendicular distance), on the basis that the concepts of equivalent permeability and representative elementary volume (REV) are tenable at the scale of the flow and transport volume of interest (Zimmerman and Bodvarrson 1996; Odling et al. 1999; Müller et al. 2010). Permeability $(k)$ and porosity $(p)$ were calculated for mechanical units of stratabound joints using the cubic flow law (e.g. NRC 1996; Zimmerman and Bodvarsson 1996; Schwartz and Zhang 2003), assuming horizontal flow through regular spaced fractures with constant aperture (Reiss 1980; Motyka 1998; Müller et al. 2010 and refs therein; Fig. 10). This relationship can be shown graphically as a power-law increase in $k$ associated with larger bed thicknesses and joint apertures (orange arrows on Fig. 10), and with apertures accentuated by the increased propensity to dissolution of thicker-bedded, purer limestones compared to more argillaceous thinner-bedded limestones and shales and nonlimestones. Depth-related upward increases in density and aperture will also result in higher $k$ and porosity (red arrows in Fig. 10), again with increased aperture and dissolution within thicker and purer limestone beds. Equivalent lateral increases in $k$ within individual beds will also arise from decreases in depth from bedrock surface associated with erosional and dissolutional valleys at a range of scales (e.g. Figure 6). Predicted changes in $k$ and porosity linked to depth, lateral distance and karst are therefore compatible with conceptual models of changes in fissure permeability and transmissivity with depth in limestone 
Fig. 9 a Groundwater levels in Ex B Drennan borehole (see Fig.8b for location). b Total flow time-series for $\mathrm{G}$ and $\mathrm{K}$ Zones of Galmoy (Fig. 8a,b): K and G flows were measured together from Dec. 2008. It is the interception of high flows from the beginning of the $\mathrm{K}$ Zone in particular (as shown on Fig.8b) that causes drawdown at Ex B

Drennan borehole from Jan 2003 onwards (P. McDermott, Lundin Galmoy Mines, personal communication, 2017). These data show that from approximately Nov 2007, groundwater levels stop declining and flows generally match groundwater levels, characteristics of which are an indicator of steady-state conditions (a)

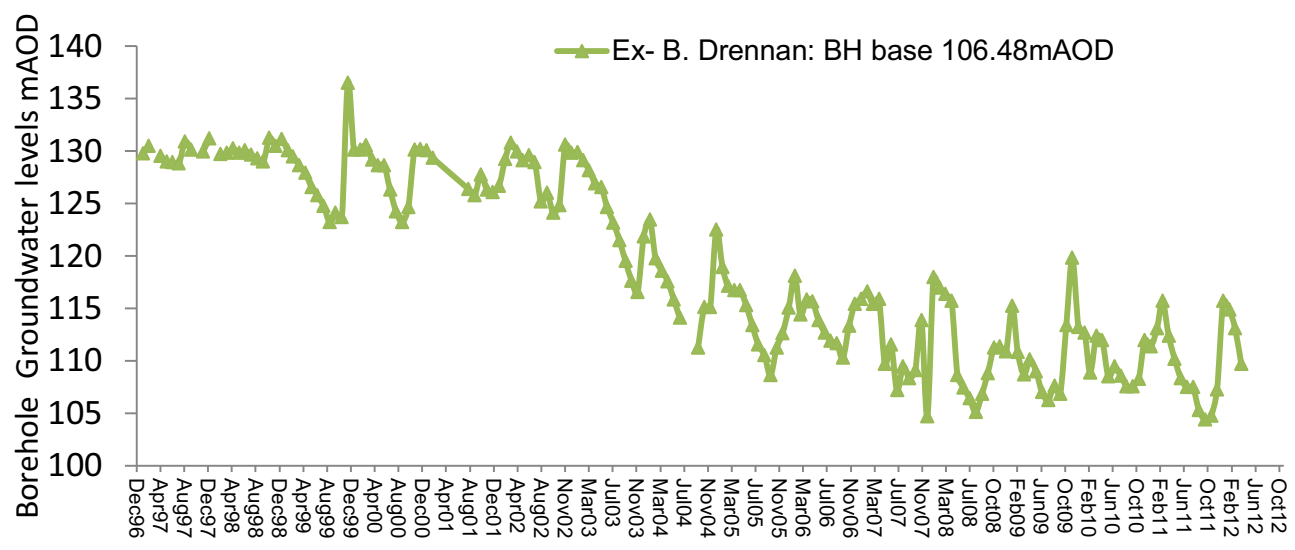

(b)

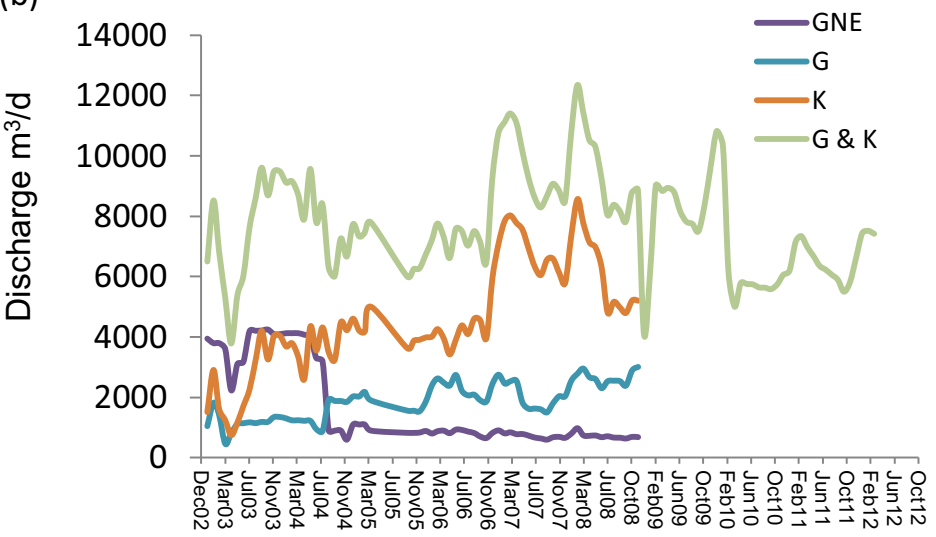

aquifers of Ireland (Fig. 7), and associated increases in water strikes and more sustainable flows at shallower depths (see section 'Discussion'). Whilst a $k$ vs $p$ plot usefully highlights controls on bed thickness and depth-related changes in horizontal permeability and porosity of stratabound joints, associated estimates of bulk permeability assume a continuum (of a laterally persistent, horizontal jointed bed). This approach does not, for example, account for the potential flow connectivity of more persistent preexisting structures on which jointing localises, such as bedding planes and steep preexisting tectonic structures (e.g. Variscan veins and Cenozoic strike-slip faults and associated fractures, as described for Fig. 6). Localisation on earlier structures has direct negative implications for defining any scale on which $k$ and/or $p$ are representative (Freeze and Cherry 1979 and refs therein; NRC 1996; Neuman 2005 and refs therein). Potential related changes in fracture scaling and flow reinforce the importance of mapping geological and geomorphological controls on spatial variations in joint aperture, density and persistence. Any such changes could also have implications for recharge which depends greatly on vertical $k$, something that is not parameterised within Fig. 10. In cleaner, thicker-bedded or massive limestones characterised by large metre- or decametre-scale joint spacings which are strongly karstified, it is even possible an REV may only be applicable at scales in excess of $10 \mathrm{~s}$ of metres, an issue which may be challenging in some circumstances. In that sense, the approach embodied in Fig. 10 is an intrinsically two-dimensional (2D) consideration of fracture-controlled flow which, for example, takes no account of the importance of subhorizontal jointing along bedding planes to provide flow connectivity between vertical joints and steep Cenozoic faults (e.g. Fig. 6a,b), particularly where karstified. The increases in flow connectivity arising from subhorizontal jointing could be responsible for the differing flow response of vertical wells in bedded versus massive limestones in some parts of Ireland, an issue referred to in section 'Discussion'.

\section{Discussion}

Faults and fractures of Cenozoic to recent age together represent the most common structures within the Carboniferous bedrock aquifers covering much of Ireland, with ubiquitous stress-release joints in the shallow subsurface $(<$ ca. $10 \mathrm{~m})$ and the widespread presence of NNW- (to NE-) trending strikeslip faults that extend to depths of more than several hundreds of metres (as observed in mines). Host rock limestone and 


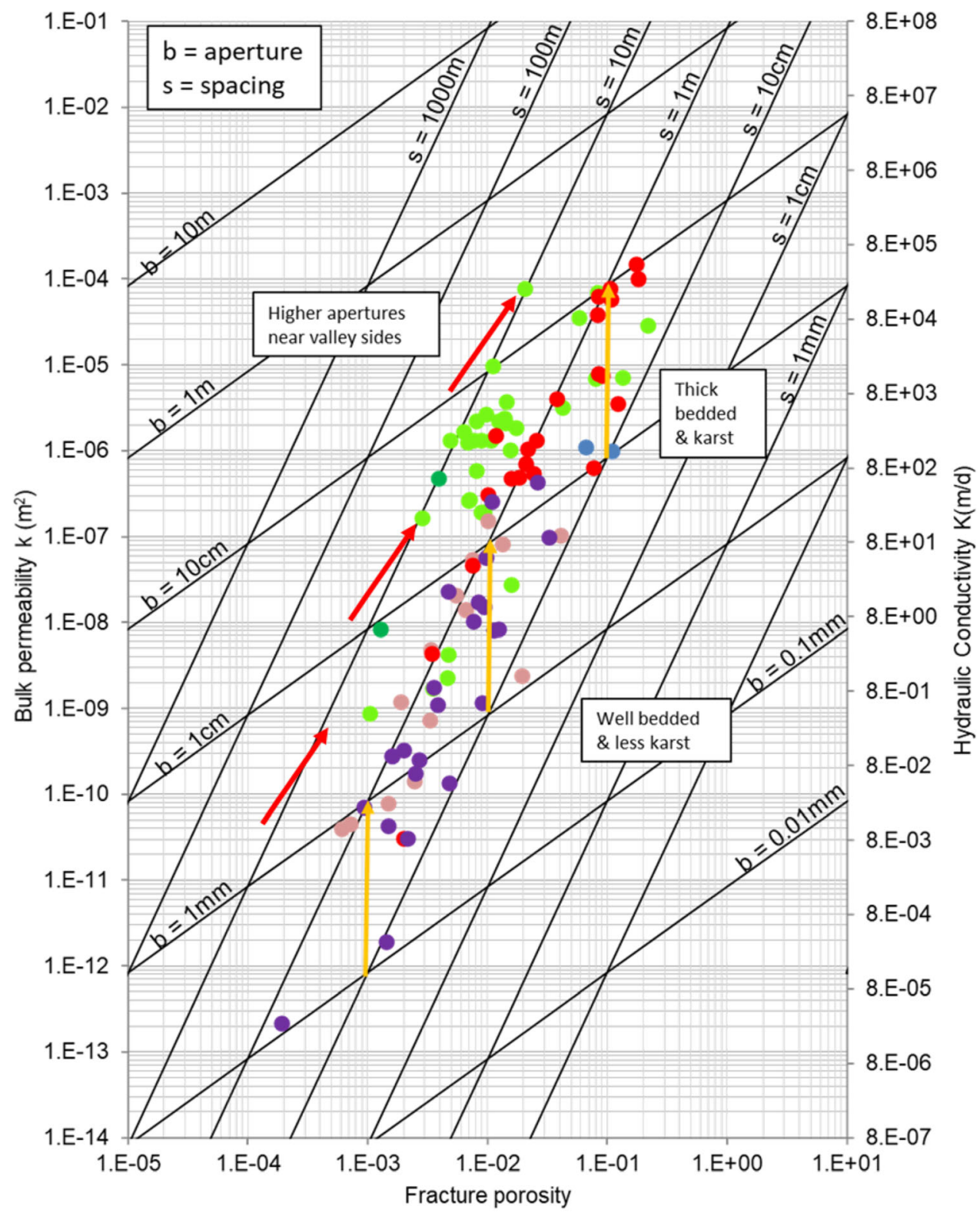

Kilkenny - Kiltorcan Formation, med to thick and occasionally thin bedded sandstone and mudstone.

Kilkenny - Ballyadams Formation, med to thick bedded stylotised limestone.

Kilkenny - Ballyadams Formation, thick bedded stylotised limestone.

Kilkenny - Aghmacart Formation, med bedded, stylotised argillaceous limestone.

- The Burren - Finavarra Member (Tubber Formation), med to thick bedded, stylotised limestone.

Meath - Loughshinney Formation, thin to medium and occasionally thick, argillaceous limestones with 1.6 to 2.6 shale layers per $\mathrm{m}$.

Fig. 10 Bulk permeability derived from the cubic law $\left(k=\frac{b^{3}}{12 s}\right.$; Schwartz and Zhang 2003), using average spacing (' $s$ ' on the lines of different spacing) and average aperture (' $b$ ' on the lines of different aperture) versus fracture porosity as percentage $\left(p=\frac{b}{s}\right)$ for joints in individual beds/mechanical units in different lithologies (plot adapted from Reiss
1980). Hydraulic conductivity (m/day) on the secondary (right-hand) axis was derived from multiplying the plotted permeability values $\left[k\left(\mathrm{~m}^{2}\right)\right]$ by the estimated values for the properties of water, gravitation, density and dynamic viscosity at ambient temperature $\left(15.50^{\circ} \mathrm{C}\right.$; e.g. in Schwartz and Zhang 2003) 
limestone-shale sequences are classic fractured aquifers, insofar as they have very low porosity and permeability in the absence of fractures and associated karst. From that perspective, the presence of Cenozoic faults and joints, together with related karst, can combine to provide the groundwater flow and storage within the limestone bedrock aquifers of Ireland. Here, some of the main issues relating to entirely fracture- and karst-controlled groundwater flow associated with these structures are briefly considered.

Joint systems provide a framework for enhanced fracture permeability and transmissivity arising from intense fracturing, karst and weathering (Fig. 7; Fitzsimmons et al. 2005; GSI 2019). This zone is referred to as the epikarst in karstified limestone systems (Jones 2013; Drew 2018), but is also important for shallow bedrock flow in nonkarstified systems (Martel 2017; Ofterdinger et al. 2019). Epikarst has a significant control on the nature of the transition zone into subsoil, and together they can provide much increased groundwater flow in the shallow bedrock (usually $<10 \mathrm{~m}$; Fitzsimmons et al. 2005; Moore and Walsh 2013; Kelly et al. 2015; Drew 2018; Medici et al. 2019a and b). The depth of highly fractured shallow bedrock varies with the mechanical properties of the host rock, because of a variety of underlying processes. The thickness dependence of joint densities requires that for a given amount of unloading and associated stress-release jointing within a host rock, thicker limestone beds will be marked by fewer joints but with greater aperture. Combined with the power-law relationship between aperture and flow, thicker beds will contain deeper penetrating joint systems with larger joint apertures that are more prone to dissolution and karstification. What these factors mean is that within the limestone-shale sequences, thicker-bedded limestone sequences will provide thicker transition zones and epikarst, with higher, more sustainable flows and potentially more rapid contaminant transport. By contrast, thinner-bedded limestone and shale sequences, which are also typically shalier, will have higher-density joint systems which are less penetrative with less sustainable flows and less rapid transport because (1) beds are thin and joints are shorter with smaller apertures, (2) mechanical and flow decoupling is promoted by shale interbeds which do not dissolve and (3) the shaley limestone beds are less prone to karstification. These factors and processes are consistent with conceptual models for the flow properties of limestone aquifers in Ireland (Fig. 7; Fitzsimmons et al. 2005), in which better aquifers are thicker bedded limestone sequences with deeper penetrating, more karstified and transmissive fracture systems, while poorer aquifers are typically thinner-bedded limestone-shale sequences with shallower, poorly karstified and less transmissive fracture systems.

An apparently contradictory observation to a model in which there is a correlation between limestone bed thickness and groundwater flow, is that relative to thick-bedded limestones, the massive poorly bedded limestones, including the Waulsortian limestones overlying the Galmoy and Lisheen ore bodies, are often classified as relatively poor aquifers over much of Ireland (Fitzsimmons et al. 2005 and refs therein). This classification is attributed to the importance of bed-parallel fractures and associated karst within thick-bedded limestones, features which promote the flow connectivity of fracture systems by linking approximately vertical fractures and conduits. The resulting network is less heterogeneous and has much better flow connection, and it is more easily accessed by conventional vertical wells that are often the determinant of aquifer performance. Water strikes in massive limestones, by contrast, require intersections between steeply inclined wells and near-vertical fractures, whether they are joints or strike-slip faults, which presents a challenging sampling issue that is common within applied fracture studies (Terzaghi 1965). This directional bias can be overcome in two main ways, by changing the inclination of wells or by the presence of shallow dipping to horizontal structures. In Galmoy Mine, for example, massive limestones are excellent aquifers when they are produced from subhorizontal roadways, the sampling equivalent of the horizontal wells sooften used to produce hydrocarbon naturally fractured reservoirs (Nelson 2001). Whilst horizontal wells are not practical for groundwater production in Ireland, inclined wells could provide significant increases in fracture intersections with associated improvements in aquifer performance. Further to the south of Ireland, massive limestone aquifers provide more sustainable yields, a scenario attributed to the appearance of subhorizontal shallow dipping thrusts and associated deformation as the Variscan fold and thrust belt is approached (Fig. 1). For example, the highest and most sustainable springs in Ireland arise from the Waulsortian limestones in the southern part of Ireland, in the vicinity of mapped thrusts (e.g. along the Killarney-Mallow Thrust and those observed in Laffansbridge Quarry; Figs. 1 and $4 \mathrm{~b}$ ), an observation which highlights how the localisation of conductive fracturing and karst on preexisting structures has resulted in higher, more sustainable flows (Moore and Walsh 2013, 2019).

Concepts such as 'representative elementary volume' and continuum-based approaches often underpin estimates of the effective flow properties of fracture systems and predictive flow models (e.g. Freeze and Cherry 1979 and refs therein; NRC 1996; Zimmerman and Bodvarrson 1996; Odling et al. 1999; Nelson 2001; Neuman 2005 and refs therein; Müller et al. 2010; Quinn et al. 2012; Maldaner et al. 2018; Medici et al. 2019a; Quinn et al. 2020). Continuum-based approaches include the use of Darcy's Law for groundwater flow modelling and estimation of hydraulic conductivity and transmissivity, and in some instances incorporate the effects of pipes and turbulent flow e.g. the MODFLOW Conduit Flow Process (Freeze and Cherry 1979; NRC 1996; Neuman 2005; Quinn et al. 2012; Gill et al. 2013; McCormack et al. 2017; Medici 
et al. 2019b; Quinn et al. 2020); Schuler et al. 2020b; Gill et al. 2020). The stratabound nature of joint systems suggests that their hydraulic properties can, in principle, be estimated using REV or continuum methods (NRC 1996; Zimmerman and Bodvarrson 1996; Odling et al. 1999) and, in that sense, these fracture systems are more predictable than Cenozoic faults (e.g. Müller et al. 2010). Individual joints do not usually provide the high sustainable flows that can be recorded on Cenozoic faults, rarely representing major pathways for groundwater flow at depths greater than ca. $10 \mathrm{~m}$. In those circumstances, the simple approach described here using fracture densities and apertures (Fig. 10) offers a useful means of illustrating and investigating the effects of stratabound joints on near-surface and transition zone porosities and flow. It highlights the strong nonlinear relationship between bed (or mechanical layer) thickness and bulk permeability, and the very significant increases in flow and storage arising from proximity to the bedrock surface and karst enhanced flow pathways (i.e. fracture apertures). The approach does not, however, account for the connectivity of conductive joint systems (NRC 1996), particularly resulting from mechanical unit interfaces (often bedding planes) and nonstratabound preexisting structures. Consideration of flow connectivity for groundwater resource and contaminant transport pathways can, however, be much improved by using threedimensional (3D) modelling approaches together with the fracture attributes measured here (NRC 1996; Parker et al. 2019). Discrete fracture network (DFN) modelling is widely applied where groundwater flow is dominated by fractures and the matrix permeability is negligible, and provides more versatile modelling solutions accounting for a number of factors highlighted by this and other studies (e.g. Sahimi 1995; NRC 1996; Dershovitz et al. 2000; Rawnsley and Wei 2001; Müller et al. 2010; Lei et al. 2017; Parker et al. 2019). This study highlights two important issues which need to be accounted for in flow models of joint systems. Firstly, the vertical and lateral variations in stress release (affecting joint density, aperture and depth of penetration) are sensitive to near-surface topography and the mechanical stratigraphy close to the bedrock surface, circumstances which may need to be accounted for in some areas. Secondly, karstification will provide depth-related and lithologically controlled changes in the storage and flow of near-surface jointed rocks, i.e. 'epikarst' (Jones 2013; Drew 2018), a feature often identified during the characterisation of fractured carbonate flow systems in general (Sasowsky and White 1994; Medici et al. 2019a and b).

Depth-related joint structure and karstification effects can, in principle, be parameterised and upscaled for incorporation into hydrogeological models as near-surface zones of diffuse flow (Gill et al. 2013; McCormack et al. 2017; Schuler et al. 2020b; Gill et al. 2020); however, the impact of older structures on jointing and karstification is more difficult to deal with. Joints immediately adjacent to, and controlled by stress release of, older structures (such as normal faults, Variscan veins and Cenozoic faults) can penetrate to well beyond $10 \mathrm{~m}$ depth and to some extent inherit the scale-independent geometries and spatial distributions of preexisting structures. In view of the potentially scale-independent nature of these earlier structures, their inclusion in flow models is more challenging (Odling et al. 1999). This is especially well illustrated by the limestone sequences of The Burren area in the west of Ireland (Fig. 1) where pervasive dissolution structures along horizontal and vertical fractures are generally restricted to the upper 2-3 $\mathrm{m}$ of the bedrock surface. At greater depths and in the absence of Cenozoic faults, which appear to be rarely developed in the west of Ireland, approximately N-S, steep Variscan veins and subhorizontal bedding planes form the principal loci for cave systems that can extend to more than $200 \mathrm{~m}$ below the surface (MacSharry 2006; Moore and Walsh 2013; Drew 2018; Walsh et al. 2019). In this area, the prevalence of karst has meant that hydrological modelling has involved the use of water levels in karst lakes (Turloughs) for the calibration of flows in groundwater catchments of discrete conduit (i.e. pipe) networks at depth and diffuse 'epikarstic' flow at shallower levels (McCormack et al. 2017; Gill et al. 2013; Schuler et al. 2020b; Gill et al. 2020). This type of approach is similar to fracture and pipe flow models used elsewhere where longer and wider conduits are modelled using laminar to turbulent flow equations (Hill et al. 2010; Medici et al. 2019b; Gill et al. 2020) and a contributing fracture system or 'epikarstic' flow is represented as a continuum using Darcy's Law (laminar flow; McCormack et al. 2017; Gill et al. 2013; Medici et al. 2019b; Schuler et al. 2020b; Gill et al. 2020). Whichever methods are employed, however, the parameterisation and modelling of complex fracture systems will always benefit from local geological constraints, maps and conditioning, combined with more detailed hydraulic monitoring and analysis similar to the flow response type approach employed for Galmoy.

Some fault/fracture systems such as the Cenozoic strikeslip faults, have scale-independent, nonstratabound characteristics with structures covering a broad range of scales (e.g. apertures) and with spatial distributions that are strongly clustered rather than periodic (Odling et al. 1999; Seebeck et al. 2014). Very heterogeneous variations in dilatancy and structural complexity even along individual structures, together with complexities arising from the linkage and connectivity of faults (Moore and Walsh 2013; Manzocchi 2002; Zhang and Sanderson 2002; Sanderson and Nixon 2018; Moore and Walsh 2019), will further mitigate against an REV and continuum approaches. In limestone host rocks, these scaling issues may be compounded by the heterogeneous localisation of karst on the same structures, with the predictive capabilities of existing approaches severely challenged. Strategies for optimising hydrocarbon production include discrete fracture 
modelling and flow simulation (e.g. NRC 1996; Dershovitz et al. 2000; Rawnsley and Wei 2001), the drilling of multiple and horizontal wells, targeting of seismically imaged structures and reservoir stimulation by hydraulic fracturing (e.g. NRCs 1996; Odling et al. 1999; Nelson 2001; Rawnsley and Wei 2001; Mäkel 2007). Flow heterogeneity is the hallmark of fractured reservoirs and the importance of well placement is paramount for fault/fracture systems with scale-independent characteristics, particularly within karstified limestones (e.g. NRC 1996; Odling et al. 1999; Nelson 2001). By contrast, hydrogeological applications within fractured aquifers do not often have recourse to seismic imaging, aquifer stimulation and multiple/horizontal wells and are, to a greater extent, encumbered by the notion of unique or measurable transmissivities for given volumes of rock. The application of continuum through to discrete fracture flow modelling and simulation should provide an improved predictive capability, for directly estimating flow volumes and velocities for assessing resources and contaminant transport potential (Quinn et al. 2012; Maldaner et al. 2018; Parker et al. 2019; Medici et al. 2019b; Gill et al. 2020; Quinn et al. 2020). The analysis performed here, however, reinforces the requirement for multiple scenario modelling, with much improved structural and hydrogeological parameterisation from future studies, particularly given the sensitivity of groundwater flow and connectivity to fault/fracture density, geometry, aperture and related karst.

This study has shown that hydrogeological projects can benefit from the availability of outcrop, quarry and mine exposures within a given area, rather than having to rely on generic analogues from very different areas and geological settings, as is often the case for hydrocarbon studies. The use of outcrop-derived structural constraints from local or equivalent geological settings provides an excellent basis for improving assessments of resources and contaminant transport. These constraints suggest, for example, that the best means of optimising the production of groundwater from Cenozoic faults in the limestone aquifers of Ireland is the targeting of individual larger faults and zones of complexity, with inclined and oriented wells, and where possible within thick-bedded limestone host rocks. The importance of fault and fracture-related karst for groundwater resource and contaminant transport has been informed by outcrop analogues in this and other recent studies (e.g. Moore and Walsh 2013, 2019; Bauer et al. 2016; Medici et al. 2019a, b; Clauzon et al. 2020)-for example, Medici et al. (2019a, b) have recognised the importance of localised cavities on normal faults affecting Permian Magnesian Limestones in the UK and incorporated them discretely within contaminant transport models. The Cenozoic faults investigated in this study (Fig. 2) have also been identified in other areas and within different host rocks such as within the Tertiary basalts of Northern Ireland and the granites of SW England. In both areas, these faults have important impacts on groundwater flow, and they are the main focus for prospective deep geothermal systems in SW England (Yeomans et al. 2020). The principal outcome of this and other structural leaning hydrogeological studies is, therefore, recognition of the importance of field studies, outcrop analogues and both geological and geomorphological mapping (Hickey 2010; Moore and Walsh 2013), in the definition of the structural framework of a study area with recourse to multiple wells, where possible. This study reinforces the relatively fundamental tenets that vertical wells can provide a very poor basis for parameterising flow models and targeting resources, and that preexisting structures can be the locus for later conductive fractures and associated karst. It also provides a basis for improvements in a variety of practical tasks, including the interpretation of groundwater flow response, the definition of optimal well locations and orientations for maximising groundwater production, and the prediction of potential conductive pathways for contaminant flow.

\section{Conclusions}

This study focusses on defining the principal characteristics and flow impact of Cenozoic strike-slip faults and joints, the youngest and the most intrinsically conductive fractures within the bedrock of Ireland. A variety of conclusions have been drawn from structural geological and hydrogeological constraints derived from the analysis of outcrop, quarry and mine datasets. The findings of this study are believed to have generic and practical implications for the analysis of fault and fracture systems within limestone and shale sequences in other geological settings.

- The dominant means of permeability in the Carboniferous limestone sequences of Ireland are NNW-NE Cenozoic faults and joints, and associated karst.

- Joints are recently formed stress-release (i.e. unloading) structures that are often intrinsically stratabound and regular spaced, with fracture densities decreasing with bed thickness and depth. They are a ubiquitous feature of the bedrock of Ireland and together with associated karstification provide combined epikarst and transition zones, usually less than $3 \mathrm{~m}$, but sometimes greater than $10 \mathrm{~m}$ thick.

- Cenozoic strike-slip faults are nonstratabound systems which show fracture-density clustering on a range of scales, with longer and bigger displacement faults transecting and displacing different mechanical layers. They show a regional eastward increase in density and displacement across Ireland, principally in the form of NNW trending dextral strike-slip faults rather than NEtrending sinistral faults and are attributed to Alpinerelated $\mathrm{N}-\mathrm{S}$ compressional deformation. 
- Quantitative models for the heterogeneity of Cenozoic faults and fractures, and for the densities and apertures of stratabound joints, provide constraints on spatial variations in groundwater flow.

- Increases in fracture density, fracture aperture and karstification towards the bedrock surface provide a basis for nonlinear upward increases in transmissivity.

- A $k$ vs $p$ plot of bed-scale permeability $(k)$ and porosity $(p)$ values for stratabound joints in different lithological sequences highlights important controls on spatial variations in flow arising from changes in bed thickness, depth and karst-related dissolution.

- Horizontal flow estimates to vertical wells do not capture the aquifer properties of fracture systems, which are much improved within bedded rather than massive limestones, because bed-parallel fracturing and karst-related dissolution provide flow connectivity between the ubiquitous vertical faults and fractures.

- Flow and level data, including flow rates, cumulative flow and along-fault drawdown, highlight the flow heterogeneity within fractured aquifers containing Cenozoic strikeslip faults, with flow rates varying from up to $100,000 \mathrm{~m}^{3} /$ day to zero, even on metre scales along individual faults.

- Heterogeneous flow at different scales arises from the importance of fracture clustering and vuggy and/or karstified conduits, with fracture connectivity promoted by the presence of subhorizontal bed-parallel joints, thrusts and karst.

- Fracture-related flow systems are best investigated by reconciling quantitative geological parameterisation and mapping, with analysis and monitoring of flow response.

- This study has concentrated on investigating the impact of Cenozoic faults and joints on groundwater flow, but the potential influence of preexisting structures is also an important consideration for individual hydrogeological case studies.

Acknowledgements We thank the EPA, GSI, mine owners and quarry owners for data. We are very grateful to David Ball, Donal Daly, Tom Manzocchi, Bruce Misstear, Ulrich Ofterdinger and Taly Hunter Williams for discussions, advice and encouragement. We would like to acknowledge Uwe Tröger and the International Association of Hydrogeologists (IAH) Chaves 2017 conference team for arranging the associated conference and topical volume. We also thank Martin Appold (editor), Giacomo Medici, Alain Rouleau and an anonymous reviewer for their helpful reviews of this report.

Funding Open Access funding provided by the IReL Consortium. We gratefully acknowledge financial support from the EPA STRIVE Programme and thank the EPA and the Department of Environment, Community and Local Government (DECLG) for their support under the National Development Plan 2007-2013. This report has emanated from research that is supported in part by a research grant from Science Foundation Ireland (SFI) under grant number 13/RC/2092 and co-funded under the European Regional Development Fund.
Open Access This article is licensed under a Creative Commons Attribution 4.0 International License, which permits use, sharing, adaptation, distribution and reproduction in any medium or format, as long as you give appropriate credit to the original author(s) and the source, provide a link to the Creative Commons licence, and indicate if changes were made. The images or other third party material in this article are included in the article's Creative Commons licence, unless indicated otherwise in a credit line to the material. If material is not included in the article's Creative Commons licence and your intended use is not permitted by statutory regulation or exceeds the permitted use, you will need to obtain permission directly from the copyright holder. To view a copy of this licence, visit http://creativecommons.org/licenses/by/4.0/.

\section{References}

Abesser C, Shand P, Ingram J (2005) Baseline report series: 22. the Carboniferous Limestone of northern England. British Geological Survey commissioned report no. CR/05/076N, BGS, Keyworth, UK

Allen DJ, Brewerton LJ, Coleby LM, Gibbs BR, Lewis MA, MacDonald AM, Wagstaff SJ, Williams AT (1997) The physical properties of major aquifers in England and Wales. British Geological Survey technical report WD/97/34, Environment Agency R\&D Publication 8, BGS, Keyworth, UK, 312 pp

Allmendinger RW, Cardozo N, Fisher D (2012) Structural geology algorithms: vectors and tensors. Cambridge University Press, Cambridge, UK

Anderson H (2013) The origin and nature of Cenozoic faulting in northeast Ireland and the Irish Sea. PhD Thesis, University College Dublin, Ireland

Anderson H, Walsh JJ, Cooper MR (2016) Faults, intrusions and flood basalts: the Cenozoic structure of the north of Ireland. In: Young ME (ed) Unearthed: impacts of the Tellus surveys of the north of Ireland. Royal Irish Academy, Dublin. https://doi.org/10.3318/978-1908996-88-6.ch14

Anderson H, Walsh JJ, Cooper MR (2018) The development of a regional-scale intraplate strike-slip fault system: alpine deformation in the north of Ireland. J Struct Geol. https://doi.org/10.1016/j.jsg. 2018.07.002

Archer JB, Sleeman AG, Smith DC (1996) Geology of Tipperary and adjoining parts of Laois, Kilkenny, Offaly, Clare and Limerick, to accompany the bedrock geology 1:100,000 scale map series, sheet 18, Tipperary with contributions by K. Claringbold, G. Stanley (mineral resources) and G. Wright (groundwater resources). Geological Survey of Ireland, Dublin

Ball D (2007) Understanding groundwater flow systems for local water supplies in Ireland. Irish Association of Hydrogeologists, Proceedings of 27th annual conference, 'Groundwater: opportunities and pressures', Tullamore, Ireland, pp 2-1-2-8. http://www. iah-ireland.org/conference-proceedings/2007.pdf. Accessed August 2021

Ball D, Geological Survey of Ireland, Health Service executive and Environment Protection Agency (2013) EPA drinking water advice note. Advice Note no. 14: borehole construction and wellhead protection. https://www.epa.ie/pubs/advice/drinkingwater/EPA_ DrinkingWater_AdviceNoteNo14b_web.pdf. Accessed August 2021

Bauer H, Schröckenfuchs TC, Decker K (2016) Hydrogeological properties of fault zones in a karstified carbonate aquifer (northern Calcareous Alps, Austria). Hydrogeol J 24:1147-1170. https://doi. org/10.1007/s10040-016-1388-9 
Blake S (2016) A multi-disciplinary investigation of the provenance, pathways and geothermal potential of Irish thermal springs. $\mathrm{PhD}$ Thesis, National University of Ireland, Galway, Ireland, 179 pp

Blake S, Henry T, Müller MR, Jones AG, Moore JP, Murray J, Campanyà J, Vozar J, Walsh JJ, Volker R (2016) Understanding hydrothermal circulation patterns at a low-enthalpy thermal spring using audio-magnetotelluric data: a case study from Ireland. J Appl Geophys 132:1-16

Blake S, Henry T, Moore JP, Murray J, Campanyà J, Müller MR, Jones AG, Rath V, Walsh J (2021) Characterising thermal water circulation in fractured bedrock using a multi-disciplinary approach: a case study of St. Gorman's well, Ireland. Hydrogeol J. https://doi.org/10. 1007/s10040-021-02393-1

Cai Z, Ofterdinger U (2016) Analysis of groundwater-level response to rainfall and estimation of annual recharge in fractured hard rock aquifers, NW Ireland. J Hydrol 535:71-84. https://doi.org/10. 1016/j.jhydrol.2016.01.066

Clabby KJ, Bradley C, Craig M, Daly D, Lucey J, McGarrigle ML, O'Boyle S, Tierney D, Bowman J (2008) Water quality in Ireland 2004-2006. Environmental Protection Agency. https://www. researchgate.net/publication/262849587_Water_Quality_in_ Ireland 2004_-2006. Accessed August $202 \overline{1}$

Clauzon V, Mayolle S, Leonardi V et al (2020) Fault zones in limestones: impact on karstogenesis and groundwater flow (Lez aquifer, southern France). Hydrogeol J 28:2387-2408. https://doi.org/10.1007/ s10040-020-02189-9

Comte JC, Cassidy R, Nitsche J, Ofterdinger U, Pilatova K, Flynn R (2012) The typology of Irish hard-rock aquifers based on an integrated hydrogeological and geophysical approach. Hydrogeol J 20: 1569-1588. https://doi.org/10.1007/s10040-012-0884-9

Cooper MR, Anderson H, Walsh JJ, Van Dam CL, Young ME, Earls G, Walker A (2012) Palaeogene Alpine tectonics and Icelandic plumerelated magmatism and deformation in Northern Ireland. J Geol Soc Lond 169:29-36

Daly EP (1995) The principal characteristics of the flow regime in Irish aquifers. Irish Association of Hydrogeologists, Proceedings of 15th annual conference, 'The role of groundwater in sustainable development', Tullamore, Ireland. http://www.iah-ireland.org/ conference-proceedings/1995.pdf. Accessed August 2021

Dewey JF, Windley BF (1988) Paleocene-Oligocene tectonics of NW Europe. Geol Soc Lond Spec Publ 39:25-31

Dershowitz B, LaPointe P, Eiben T, Wie L (2000) Integration of discrete feature network methods with conventional simulator approaches. SPE Res Eval Eng 3:165-170

Doyle E, Bowden AA, Jones GV, Stanley GA (1992) The geology of the Galmoy zinc-lead deposits, Co. Kilkenny. In: Bowden AA, Earls G, O'Connor PG, Pyne JF (eds) The Irish minerals industry 19801990, Irish Assoc. for Econ. Geol., Dublin, pp 211-225

Drew D (2018) Karst of Ireland: landscape, hydrogeology, methods. Geological Survey of Ireland, Dublin, $318 \mathrm{pp}$

Drew D (1990) The hydrology of the Burren, Co. Clare. Irish Geography 23:69-89

Ferrill DA, Morris AP (2003) Dilational normal faults. J Struct Geol 25: 183-196

Ferrill DA, Smart KJ, Morris AP (2020) Fault failure modes, deformation mechanisms, dilation tendency, slip tendency, and conduits v. seals. Geol Soc London Spec Pub 496:75-98

Fitzsimons V, Daly D, Wright G, Hunter-Williams N (2005) Rock type versus fractures: current understanding of Irish aquifers. Irish Association of Hydrogeologists, Proceedings of 25th Annual Conference, 'Groundwater in Ireland', Tullamore, Ireland, pp 1728. http://www.iah-ireland.org/conference-proceedings/2005.pdf. Accessed August 2021

Fossen H (2010) Structural geology. Cambridge University Press, New York
Freeze RA, Cherry JA (1979) Groundwater. Prentice-Hall, Englewood Cliffs, NJ, $604 \mathrm{pp}$

Fusciardi LP, Güven JF, Stewart DRA, Carboni V, Walsh JJ (2003) The geology and genesis of the Lisheen $\mathrm{Zn}-\mathrm{Pb}$ deposit, Co. Tipperary, Ireland. In: Fusciardi L, Earls G, Stanley G, Kelly J, Ashton J, Boland M, Andrew CJ (eds) Europe's major base metal deposits. Spec Pub IAEG, pp 455-282

Geological Survey of Ireland (GSI) (2019) Transition zone. https://www. gsi.ie/en-ie/programmes-and-projects/groundwater-andgeothermal-unit/projects/gw3d/Pages/Transition-Zone.aspx. Accessed August 2021

Geological Survey of Ireland (GSI) (2018) The 1:100,000 and 1:500,000 scale bedrock geology of Ireland accessed April 2018. https://www. gsi.ie/en-ie/data-and-maps/Pages/Bedrock.aspx\#100k

Gillespie PA, Walsh JJ, Watterson J, Bonson CG, Manzocchi T (2001) Scaling relationships of joint and vein arrays from The Burren, Co. Clare, Ireland. J Struct Geol 23:183-201

Gill LW, Naughton O, Johnston PM (2013) Modelling a network of turloughs in lowland karst. Water Resour Res 49:3487-3503. https://doi.org/10.1002/wrcr.20299

Gill LW, Schuler P, Duran L, Morrissey P, Johnston PM (2020) An evaluation of semi-distributed-pipe-network and distributed-finitedifference models to simulate karst systems. Hydrogeol J. https:// doi.org/10.1007/s10040-020-02241-8

Hickey C (2010) The use of multiple techniques for conceptualisation of lowland karst, a case study from County Roscommon, Ireland. In: Special Edition: Research Frontiers and Practical Challenges in Karst Hydrogeology, Ljubljana. Acta Carsolog 39(2):331-346

Hill ME, Stewart MT, Martin A (2010) Evaluation of the MODFLOW2005 conduit flow process. Groundwater 48(4):549-559

Jones WK (2013) Physical Structure of the Epikarst. Acta Carsologica. Ljubljana, Slovenija, 42(2-3). https://doi.org/10.3986/ac.v42i2-3. 672

Kelly C, Hunter Williams T, Misstear BM, Motherway K (2015) Irish aquifer properties: a reference manual and guide. Geological Survey of Ireland and the Environmental Protection Agency. https://www. gsi.ie/en-ie/publications/Pages/IrishAquifersProperties AreferencemanualandguideVersion10March2015.aspx. Accessed August 2021

Krásný J, Sharp JM (2007) Groundwater in fractured rocks. IAH Selected Paper Series, Groundwater in Fractured Rocks International Conference, Prague, September 2003

Lei Q, Latham JP, Tsang C-F (2017) The use of discrete fracture networks for modelling coupled geomechanical and hydrological behaviour of fractured rocks. 85:151-176

Lowther JM, Balding AB, McEvoy FM, Dunphy S, MacEoin P, Bowden AA, McDermott P (2003) The Galmoy Zn-Pb orebodies: structure and metal distribution: clues to the genesis of the deposits. In: Kelly JG, Andrew CJ, Ashton JH, Boland MB, Earls G, Fusciardi L, Stanley G (eds) Europe's major base metal deposits. Irish Association for Economic Geology, Dublin, pp 437-454

MacSharry B (2006) The influence of fractures on topography and groundwater flow in the Burren and Gort lowlands, western Ireland. PhD Thesis, Trinity College, Dublin, Ireland

Mäkel GH (2007) The modelling of fractured reservoirs: constraints and potential for fracture network geometry and hydraulics analysis. Geol Soc Lond Spec Pub 292:375-403

Maldaner CH, Quinn PM, Cherry JA, Parker BL (2018) Improving estimates of groundwater velocity in a fractured rock borehole using hydraulic and tracer dilution methods. J Contam Hydrol 214:75-86

Mandl G (2005) Rock joints: the mechanical genesis. Springer, Heidelberg, Germany, $221 \mathrm{pp}$

Manzocchi T (2002) The connectivity of two-dimensional networks of spatially correlated fractures. Water Resour Res 38(9). https://doi. org/10.1029/2000WR000180 
Martel S (2017) Progress in understanding sheeting joints over the past two centuries. J Struct Geol 94:68-86. https://doi.org/10.1016/j.jsg. 2016.11.003

McCormack T, O'Connell Y, Daly E, Gill LW, Henry T, Perriquet M (2017) Characterisation of karst hydrogeology in Western Ireland using geophysical and hydraulic modelling techniques. J Hydrol 10: $1-17$

Medici G, West LJ, Banwart SA (2019a) Groundwater flow velocities in a fractured carbonate aquifer-type: implications for contaminant transport. J Contam Hydrol 22:1-16

Medici G, West LJ, Chapman PJ, Banwart SA (2019b) Prediction of contaminant transport in fractured carbonate aquifer types: a case study of the Permian Magnesian Limestone Group (NE England, UK). Environ Sci Poll Res 26:24863-24884

Misstear BDR, Brown L (2008) Water Framework Directive: recharge and groundwater vulnerability. STRIVE report no. 6, Environmental Protection Agency. 1, 36 pp. https://www.epa.ie/ publications/research/water/water-framework\%2D\%2Ddirectiverecharge-and-groundwater-vulnerability.php. Accessed August 2021

Molénat J, Davy P, Gascuel-Odoux C, Durand P (1999) Study of three subsurface hydrologic systems based on spectral and cross-spectral analysis of time series. J Hydrol 222:152-164. https://doi.org/10. 1016/S0022-1694(99)00107-9

Moore JP, Walsh JJ (2013) Analysis of fracture systems and their impact on flow pathways in Irish bedrock aquifers. Geological Survey of Ireland (GSI), Groundwater Newsletter, 51. https://www.gsi.ie/ documents/GWNewsletterNo51.pdf. Accessed August 2021

Moore JP, Walsh JJ (2019) The geological controls on groundwater flow evident from the exposure of The Burren. In: Karst hydrogeology of the The Burren Uplands/Gort Lowlands. International Association of Hydrogeologists (IAH) Irish Group. Field guide. http://www.iahireland.org/field-guides/2019.pdf. Accessed August 2021

Moore JP, Walsh JJ, Manzocchi T (2019) A definition of hydraulic connectivity in geological media. Proceedings of IAH 2019, the 46th Annual Congress of the International Association of Hydrogeologists, Málaga (Spain), September 22-27, 2019. Abstract no. 327. http://www.iah2019.org/\#. Accessed August 2021

Motyka J (1998) A conceptual model of hydraulic networks in carbonate rocks, illustrated by examples from Poland. Hydrogeol J 6:469-482

Müller C, Siegesmund S, Blum P (2010) Evaluation of the representative elementary volume (REV) of a fractured geothermal sandstone reservoir. Environ Earth Sci 61:1713-1724. https://doi.org/10.1007/ s12665-010-0485-7

Narr W, Schechter DS, Thompson LB (2006) Naturally fractured reservoir characterization. Society of Petroleum Engineers, Richardson, $\mathrm{TX}$

National Research Council (NRC) (1996) Rock fractures and fluid flow: contemporary understanding and applications. National Academy Press, Washington, DC, $551 \mathrm{pp}$

Nelson RA (2001) Geologic analysis of naturally fractured reservoirs. Gulf Professional Publishing, Houston, TX

Neuman SP (2005) Trends, prospects and challenges in quantifying flow and transport through fractured rocks. Hydrogeol J 13:124-147

Odling NE, Gillespie P, Bourgine B, Castaing C, Chilés J-P, Christensen NP, Fillion E, Genter A, Olsen C, Thrane L, Trice R, Aarseth E, Walsh JJ, Watterson J (1999) Variations in fracture system geometry and their implications for fluid flow in fractured hydrocarbon reservoirs. Petroleum Geosci 5:374-384

Odling NE, Harris SD, Knipe RJ (2004) Permeability scaling properties of fault damage zones in siliclastic rocks. J Struc Geol 26(9):17271747. https://doi.org/10.1016/j.jsg.2004.02.005

Ofterdinger U, MacDonald AM, Comte J-C, Young ME (2019) Groundwater in fractured bedrock environments: managing catchment and subsurface resources - an introduction. In: Ofterdinger U, MacDonald AM, Comte J-C, Young ME (eds) Groundwater in fractured bedrock environments: managing catchment and subsurface resources. Geol Soc Lond Spec Publ 479:1-9

Parker BL, Chapman SW, Goldstein KJ, Cherry JA (2019) Multiple lines of field evidence to inform fracture network connectivity at a shale site contaminated with dense non-aqueous phase liquids. Geol Soc Lond Spec Publ 479(1):101-127

Price N (1966) Fault and joint development in brittle and semi-brittle rock. Pergamon, Oxford, UK

Quinn PM, Cherry JA, Parker BL (2012) Hydraulic testing using a versatile straddle packer system for improved transmissivity estimation in fractured-rock boreholes. Hydrogeol J 20:1529-1547. https://doi. org/10.1007/s10040-012-0893-8

Quinn PM, Cherry JA, Parker BL (2020) Relationship between the critical Reynolds number and aperture for flow through single fractures: evidence from published laboratory studies. J Hydrol 581:124384

Rawnsley K, Wei L (2001) Evaluation of a new method to build geological models of fractured reservoirs calibrated to production data. Pet Geosci 7:23-33

Reiss LH (1980) The reservoir engineering aspects of fractured formations. Editions Technip, Paris

Roche V, Camani G, Childs C, Manzocchi T, Walsh JJ, Conneally J, Saqab MM, Delogkos E (2021) Variability in the threedimensional geometry of segmented normal fault surfaces. Earth Sci Rev 216(11):103523

Sahimi M (1995) Flow and transport in porous media and fractured rock: from classical methods to modern approaches. $\mathrm{VCH}$, Weinheim, NY

Sanderson DJ, Nixon CW (2018) Topology, connectivity and percolation in fracture networks. J Struct Geol 115:167-177

Sasowsky ID, White WB (1994) The role of stress release fracturing in the development of cavernous porosity in carbonate aquifers. Water Resour Res 30(12):3523-3530

Schöpfer MPJ, Arslan A, Childs C, Walsh JJ (2011) Reconciliation of contrasting theories for fracture spacing in layered rocks. J Struct Geol 33:551-565

Schwartz FW, Zhang H (2003) Fundamentals of groundwater. Wiley, New York

Schuler P, Stoeckl L, Schnegg P, Bunce C, Gill L (2020a) A combinedmethod approach to trace submarine groundwater discharge from a coastal karst aquifer in Ireland. Hydrogeol J 28:561-577. https://doi. org/10.1007/s10040-019-02082-0

Schuler P, Duran L, Johnston P, Gill L (2020b) Quantifying and numerically representing recharge and flow components in a karstified carbonate aquifer. Water Res Res 56:e2020WR027717. https://doi. org/10.1029/2020WR027717

Seebeck H, Nicol A, Walsh JJ, Childs C, Beetham RD, Pettinga J (2014) Fluid flow in fault zones from an active rift. J Struct Geol 62:52-64

Terzaghi RD (1965) Sources of errors in joint surveys. Geotechnique 15: 287-304

Walsh JJ, Watterson J, Yielding G (1991) The importance of small-scale faulting in regional extension. Nature 351:391-393

Walsh JJ, Watterson J, Bailey WR, Childs C (1999) Fault relays, bends and branchlines. J Struct Geol 21:1019-1026

Walsh JJ, Torremans K, Güven J, Kyne R, Conneally J, Bonson C (2018) Fault-controlled fluid flow within extensional basins and its implications for sedimentary rock-hosted mineral deposits. Soc Econ Geol Spec Publ 21:237-269

Walsh JJ, Moore JP, Bunce C, Hollis SP, Kelly J, Menuge JF (2019) The origin and nature of hydraulic fractures and veins with The Burren, County Clare, Ireland. Irish J Earth Sci 37:61-84. https://doi.org/10. 3318/IJES.2019.37.5

Walsh JJ, Childs C, Imber J, Manzocchi T, Watterson J, Nell PAR (2003) Strain localisation and population changes during fault system growth within the Inner Moray Firth, Northern North Sea. J Struct Geol 25:1897-1911 
Yeomans CM, Shail RK, Eyre M (2020) What might a fault-hosted geothermal reservoir look like? Conference paper: The 59th Annual Meeting of the Ussher Society, convened at Devon Hotel, Exeter, SW UK

Zhang X, Sanderson DJ (2002) Numerical modelling and analysis of fluid flow and deformation of fractured rock masses. Elsevier, Amsterdam
Zimmerman RW, Bodvarrson GS (1996) Effective transmissivity of twodimensional fracture networks. Int J Rock Mech Min Sci Geomech Abstr 33:433-438

Publisher's note Springer Nature remains neutral with regard to jurisdictional claims in published maps and institutional affiliations. 